\title{
Heroic History, Disruptive Genealogy: Al-Ḥasan al-Hamdānī and the Historical Formation of the Shākir Tribe (Wä ilah and Dahm) in al-Jawf, Yemen
}

\author{
Marieke Brandt*
}

Genealogies are emic forms of social representation among many tribes in the Arab world. The formability of these genealogies for the purposes of politics and alliances is a common phenomenon. It becomes particularly obvious if one looks at the case of the Shākir tribe and its main divisions Wä ilah and Dahm in the region of al-Jawf in northernmost Yemen. A comparison of their tribal genealogies and settlement areas in the tenth century CE, as described by the Yemeni scholar and historian al-Hasan al-Hamdānī, with their tribal structures and territories in the twenty-first century shows the enormous extent of change to which the Shākir, especially Dahm, have been subject in the past millennium. These changes seem to reflect in part the continuous immigration of external tribal groups to which the fringes of the Rub'al-Khàli desert have historically been exposed, and their inclusion into the local societies and thus the evolving genealogy of Shākir. These elements of residential discontinuity and mobility contrast with the more general pattern of territorial continuity and stasis prevailing in the central areas of Yemen. Yet the genealogy of Shākir proved to be more open towards these intrusive groups than towards the original inhabitants of the area itself: in contemporary al-Jawf remain descendants of ancient groups who are considered the aboriginal inhabitants of the area and who were neither given equal status to Shākir nor included into the Shākir genealogy. Seen in this light, the genealogies and semi-legendary traditions of al-Hamdāni’s al-Iklīl also served to evoke a vision of community and of common identities among the heterogeneous societies of South Arabia and to legitimize them as heirs of a country and its history, which in parts was not inherently their own.

Keywords: Al-Hasan al-Hamdānī; genealogy; tribe; Bedouins; South Arabia; Yemen

\section{The politics of genealogy}

Abū Muhammad al-Ḥasan b. Aḥmad b. Ya'qūb al-Hamdānī (d. 945 CE) belongs to the most outstanding of Yemen's scholars and historians of the early medieval period. In his works Sifat Jazirat al-'Arab and the extant parts of al-Iklil he describes the physical and tribal geography of the southern Arabian Peninsula, its historical monuments and the genealogies (nasab, pl. $a n s \bar{a} b$ ) of the South Arabian tribes, thus outlining the salient features of specific South Arabian

* Correspondence details: Marieke Brandt, Institute for Social Anthropology, Centre for Studies in Asian Cultures and Social Anthropology, Austrian Academy of Sciences, Apostelgasse 23, A-1030 Vienna, Austria, email: Marieke. Brandt@oeaw.ac.at. 
identities. ${ }^{1}$ His quest for the construction of South Arabian identities was in part a response to the creation of ideologically driven genealogies among the Arabs of the north, such as the genealogical work Jamharat al-nasab compiled by Hishām b. Muhammad al-Kalbī (d. 819), which had systematized the tribes of northern Arabia and "united « them under the symbol 'Adnān, the putative common ancestor of the Northern Arabs. ${ }^{2}$ By way of contrast to such endeavours, this also prompted an increased need for genealogical self-identification and selfrepresentation among the Arabs of the South.

When it comes to the roles of genealogies in al-Hamdānì's oeuvre, Heiss' elaborate dissertation on "Tribale Selbstorganisation und Konfliktregelung" (1998) in the Șa'dah area is the scholarly standard from where one has to start. On the basis of the information available in al-Hamdānī's works, Heiss investigates the phenomenon of formability of genealogies taking the example of the sedentary population of the Șa dah basin, among whom the formability of genealogies served as an important means of conflict resolution and conflict avoidance. In addition, al-Hamdāni’s construction of the political identities of the South Arabian tribes had two core elements. Firstly, the most accurate possible recording of the territory of the South Arabians and the description of their landscape of historical monuments, which was intended to illustrate the depth of South Arabian history and to attest the equal or even superior antiquity of the South Arabian tribes in comparison to the tribes of the North. ${ }^{3} \mathrm{Sec}-$ ondly, al-Hamdāni depicts the tribes of southern Arabia genealogically as the descendants of Qahțān, the brother of 'Adnān and legendary progenitor of the tribes of southern Arabia and symbol of unity of the »original" or "Arabian« Arabs (al-'arab al-äribah), whose bloodline accordingly is deemed purer than that of the "spurious" or "Arabicized « Arabs (al-'arab al-musta' ribah) of the North. ${ }^{4}$

Thus al-Hamdāni’s genealogical classifications and memory of the past stimulated the growth of something akin to common identities among the tribes of South Arabia and fathered a type of local historiography that was a combination of topography, cultural history, and genealogy. Al-Kalbỉ's and al-Hamdānīs genealogical works mark the completion of the codification of Arab genealogies. The distinguishing feature of their voluminous genealogical compilations is the attempt to provide the agnatic lineages not only of certain families or tribes, but rather to portray the structure and kinship system of broad regions of the Arabian Peninsula. It is thus clear that these genealogical superstructures in many, if not most cases, are constructs in the service of political ends. Through its dynamics, variability and

1 Note on transliteration: For transcribing Arabic, I have used the system of the International Journal of Middle Eastern Studies (IJMES) for both written and spoken words. Common words, such as Yemen and Saudi Arabia, are given in an Anglicized version. The Arabic bin or ibn ("son of "), where it comes between two names, has been given as simply $b$. throughout. Initial hamzah is unmarked.

Al-Hamdānī conceptualized al-Iklīl as an encyclopaedia of knowledge specifically related to South Arabia. It included ten volumes, of which only the first, second, eighth and tenth volumes are extant. For an overview of the various manuscripts and printed editions of al-Iklil and Sifah Jazirat al-'Arab, see Heiss, Tribale Selbstorganisation und Konfliktregelung, 21-33.

2 See the commentated edition by Caskel, Ğamharat an-nasab.

3 Duri, Historical Writing, 130-135; Mahoney, Cultural Heritage.

4 Caskel, Gamharat an-nasab, 1, 19-21, 40; Piotrovsky, Al-Hamdani and the Qahtanide Epos. 
continuous ability to change, tribal nasab indeed represents a special case of genealogy. ${ }^{5}$ The changeability of tribal genealogies for the purposes of politics and alliances is a common phenomenon throughout the Arab world. Studies on tribal genealogy show that descent lines are in most cases the results of manifold processes of tribal fusion and fission and sometimes even pure constructs. The dynamic character of genealogy and agnatic lineages and its significance for the development of 'asabiyyah (»solidarity group« or »esprit de corps«) and collective alliances is demonstrated for tribal societies throughout the Arab World, as shown in the pioneering contributions to this subject which assess and contextualize the notion of tribes in anthropological and historical analyses of Arab societies. ${ }^{6}$ Tribal structures and genealogies are seldom stable, but rather dynamic and deformable so that new political constellations, alliances and territorial changes can be facilitated by genealogical alignments. In many cases genealogy follows a politics of "must have been « rather than biological facts. ${ }^{7}$

What I wish to do here is to look into a special case among the tribes of Qahțān described by al-Hamdānì in the tenth volume of al-Iklìl, namely Shākir or al-Shākiriyyūn dwelling in the area of al-Jawf and its environments at the fringe of the vast Rub al-Khāli desert. I will discuss the nature of their historic tribal divisions as depicted by al-Hamdāni in the tenth century, as well as the changes Shäkir exhibited over the past millennium. The comparison of the tribal structure and settlements of Shākir in the tenth century CE with their contemporary tribal structure and settlements in the twenty-first century shows the enormous extent of change and dynamization of nasab to which Shākir have historically been exposed. It will be shown that to a certain degree the changes in the Shäkir's genealogical representations have been triggered by a continuous influx of immigrant groups from areas elsewhere at the fringes of the Rub' al-Khālī. Indeed during my fieldwork I experienced that tribal oral tradition in al-Jawf displays a record of immigration including explicit references to external encounters and interdependencies between regional and immigrant "foreign" groups from other areas. Shākir's frequent encounter with immigrant groups and their ability to absorb them into their nasab is not only a key feature of the past millennium; the consideration of

5 Tribal genealogy herein differs from the genealogy of the descendants of the Prophet Muhammad, the so-called Ahl al-Bayt or $\overline{A l}$ al-Bayt. Although the genealogy of the Ahl al-Bayt also serves the definition of group membership, this membership is immutable and can only be acquired by birth (Heiss, Tribale Selbstorganisation und Konfliktregelung, 89-90; vom Bruck, Islam, Memory, and Morality in Yemen, 102-127 and passim). Also many senior lineages among tribal leaders (pl. mashāyikh) and tribal judges (pl. qud̄á) maintain impressive family genealogies for some dozen generations. Here the knowledge of genealogies is essential for political reasons (Gingrich, Agrarkalender der Munebbih, 133-136; Weir, Tribal Order, 97-101; Dresch, Tribes, Government, and History, 102, 154 n. 21, 207 and passim; Dresch, Position of Shaykhs, 36-37.

6 On anthropological elaborations of nasab in Yemen, see Bédoucha, Tribu sédentaire and Cercle des proches; Brandt, Khawlän and Jumäa'ah; Dresch, Tribes, Government, and History, 320-360, and Tribes of Häshid-wa-Bakil; Gingrich, Agrarkalender der Munebbih, 145-159, Südwestarabische Sternenkalender, 13-17, Konzepte und Perspektiven; Heiss, Tribale Selbstorganisation und Konfliktregelung; Wilson, Al-Hamdānì's Description of Häshid and Bakìl. On nasab in further (Arab and non-Arab) tribal societies, see Bonte, Egalité et hiérarchie; Caskel, Ğamharat an-nasab; Conte, Entrer dans le sang; Evans-Pritchard, Nuer; Hamès, Filiation généalogique and Chefferie tribale; Kennedy, From Oral Tradition to Written Record; Landau-Tasseron, Adoption and Status of Allies; Ould Cheikh, Tribu; Peters, Proliferation; Szombathy, Genealogy in Medieval Muslim Societies and Roots of Arabic Genealogy.

7 Kennedy, From Oral Tradition to Written Record. In some cases the grafting of genealogies reaches such an extent that Szombathy sums up somehow indignantly that "genealogy" seems to be a translation error of the term nasab, suspecting that the term nasab actually means "relations« rather than "genealogy (Szombathy, Roots of Arabic Genealogy). 
findings from archeology suggests that al-Jawf's history of invasion dates further back to the time before the beginning of the Common Era. It will be shown that its geographic position at the fringes of the Empty Quarter perhaps makes this record of immigration more relevant than in other areas further to the west. In itself, al-Jawf indicates a specific case among a greater diversity of regional variations which also include fewer records of such immigration stories. Given the heterogeneity of Shākir tribe, both the stringent genealogies recorded by al-Hamdānī and his efforts to portray Shākir as the heirs of al-Jawf's splendid history, thus resemble constructs of a project which strives to create a vision of community and common identities in terms of genealogy and lore.

\section{The Shäkir Saga}

The task of providing a picture of Upper Yemen in the early Islamic period is fraught with difficulties. The primary sources for late antiquity and the early Islamic period of Yemen are few. To the sources of this era, in addition to the extant works of al-Hamdāni, belongs the Sìrat al-Hādì ilā al-Haqq Yahyā b. al-Husayn by 'Alī b. Muhammad b. 'Ubayd Allah al-'Abbāsī al-'Alawì which deals with the arrival and the life of the first Zaydì imām in Yemen, Yahyā al-Hādī ilā al-Ḥaqq (d. 911), and his attempts to establish his rule over the Qaḥțānì tribes in Yemen's north. ${ }^{8}$

Both al-Hamdānī's and al-'Alawì's works are stylized, but both in different ways. The Sìrah describes Imām al-Hādī's efforts to uphold and extend his sway in the northernmost parts of Yemen and to spread Zaydì religion and sharíah law among the tribes. The imām and his followers encountered hostility and opposition in the tribal society of the Northern Highlands. In the Sirah the tribes are sometimes allies, and sometimes they are the adversaries of the imām, whose tribal opponents were regarded the enemies of Islam. ${ }^{9}$ Al-Hādìs fourteen-year reign, though propitiously launched, thus resembled one of constant warfare to restore discipline over rebellious tribes, to halt renewed intertribal hostilities, and to extend Zaydì influence. The biography of al-Hādì is only the beginning of a long tradition of Yemeni historiography in which the tribes hardly appear except as they oppose or support a succession of imāms. Later historiographies, in their zeal to establish the new faith, attempted to stamp out all vestiges of paganism from South Arabia and everything that had its roots in the old order, which was to usher in the Dark Ages of the Jähiliyyah.

In contrast, al-Hamdāni's account is the first and the last extant work to deal with tribes in terms of furüsiyyah (horsemanship, chivalry, skill at arms). He portrays the descendants of Qaḥțān as South Arabian heroes, chivalrous warriors or horsemen (fursān), brandishing their swords, moving about the land and seeking honour in glorious battles and through poetry. The concept of furüsiyyah is the organising theme of the tenth volume of al-Iklil which deals with the genealogy and segmentation of the tribes of Hamdān. A great number of horsemen, heroes and noble dynasties appear in al-Hamdānīs works, the lords of al-Du'ām (Bakīl) and al-Daḥhạa (Hāshid) being the most prominent. ${ }^{10}$

9 Gochenour, Penetration of Zaydì Islam; Heiss, Tribale Selbstorganisation und Konfliktregelung, 7, 10.

10 On Upper Yemen's power structures in the Early Islamic period, see Wilson, Al-Hamdāni’s Description of Hāshid and Bakili; and Gochenour, Penetration of Zaydì Islam. 
Al-Hamdānīs writings are illuminated by the last rays of a splendid world which was already exposed to decay. The semi-legendary traditions of the eighth volume of al-Iklil on the historical monuments of South Arabia are a particularly rich repertoire of myths and collective memories. By conjuring the spirits of the past, it mirrors the charmed world of a mythical past: a world of magic places, ruins, peaks and wells inhabited by jinn, ancient divinations, supernatural ordeals and magic talismans. Since it was customary among the kings of ancient South Arabia to entomb with the dead their abundant riches, those who went out to the tombs to secure their buried treasures found inscribed tablets in the graves attached to the withered mortal remains of their putative ancestors. Their ancestors spoke to them through these tablets in a language of vanitas and reminded them of the transience of earthly life; the second part of the eighth volume of al-Iklil resembles a meditation on the ephemeral nature of life itself. This may seem morbid at first sight, but the suggestion of vanitas and memento mori themes in al-Iklìl is deceptive: at the time of al-Hamdāni the dead forefathers and their mortal remains enjoyed a venerable physical existence far beyond death and connected the living with the glorious past of their country and their dead putative ancestors.

In his Sifah, al-Hamdānì has handed down a poem by a knight of Hamdān tribe who wrote it, probably towards the end of the pre-Islamic period, about the town of Main, the ancient capital of the pre-Islamic Minaean kingdom based in the area of al-Jawf. ${ }^{11}$ This poem portrays the people of al-Jawf as heirs and protectors of the withered Minaean kingdom and as members of an elite that was chosen to continue its ancient history. What follows is an extract from the poem:

Ours are the best horses in the world

We are wearing shining armour

And carry swords we inherited from 'Ād

We shall protect the Jawf as long as Ma'in exists

Down there in the valley, opposite 'Arda!

Should anyone wish to take it from us we shall pursue him

To the heights of Yamāmah and Jarādah

If need we shall sleep with the foxes

And with the foxes in their lair

And a meal we shall prepare

From what is left of their prey. ${ }^{12}$

The continuous reference to the interconnection between the living and their dead putative ancestors inspires pride and a feeling of togetherness, in the case of this poem directly harkening back to the prosperity of the Minaean kingdom based in al-Jawf. Numerous other poems and verses tell us of the courageousness and heroism of the chivalrous horsemen of Qahțān pedigree. Yet among all these noble heroes of Qaḥțānī descent al-Hamdānī identifies Duhmah, the descendants of Shākir b. Bakīl, as the bravest. In his Șifah in the chapter on the "Marvels of Yemen, which have no equal in other countries", al-Hamdānī mentions Duhmah separately:

Jabal Baraț. Its people are the bravest of Hamdān, protectors of women and defenders of those entrusted to their protection [...] They are called the Quraysh of Hamdān. ${ }^{13}$ 
Al-Hamdānīs descriptions of Duhmah encapsulate and exemplify qualities that pertain to the South Arabian horsemen of Qahțān pedigree mentioned in the panegyric poetries by early Yemeni poets. ${ }^{14}$ The people of al-Jawf serve as a metaphor for courageousness and grandeur, embodying timeless qualities which still pertain to the ideals of the tribal societies of Yemen: honour, strength, and the idea of noble protection of the weak. A tribesman is expected to be shariff, qawì, māni i, i.e. noble, strong, and able to protect. These attributes are inseparable, and they apply as much to the tribe as to the particular man. ${ }^{15}$ Yet in his description of Duhmah, al-Hamdāni does not omit the downside of their heroism, describing Duhmah and Wä ilah as indomitable avengers whose exaggerated code of honour at times turned into rancorous deeds:

In our time the number of deaths between Duhmah and their sister (tribe) Wä' ilah, both descendants of Shākir, reached 300 men. One noble was killed for another. This happened because of a protégé of Wă ilah whom Duhmah had killed. They were the fiercest enemy who assailed them. ${ }^{16}$

Al-Hamdānì elaborates in his works the genealogies of the Qaḥtānì tribes of South Arabia who are divided into two major groups, namely the descendants of Himyar ( $q a b \bar{a}^{\prime} i l$ himyariyyah) and Kahlān ( $q a b \bar{a} \bar{a}^{\prime} i l$ kahlāniyyah). Himyar became progenitor of the major descent groups or confederations of Quḍāah and al-Humaysa'; Kahlān became progenitor of the confederations of Hamdān, al-Azd and Madhhị. The descendants of Hamdān further subdivide into Hāshid and Bakīl. All these tribes further subdivide extensively. Their perceived common ancestry corresponds to the common visual representation of tribes as "segmentary groups «: tree-like structures, which divide and subdivide in the manner of the branches of a tree, though there is no central and pre-eminent trunk, all branches being equal (Fig. 1). ${ }^{17}$

14 Jāzim and Arbach, Mérites véritables.

15 Serjeant, South Arabia, 227-228; Dresch, Tribes, Government, and History, 38-74, 117-136.

16 Al-Hamdānī, Șifah, 194-195.

17 The segmentary model was introduced by Evans-Pritchard with regard to the Cyrenaican Bedouins and further elaborated by Gellner for the Berbers of the High Atlas. The socio-political implications of the segmentary model have been challenged by several anthropologists and are now considered defunct (Caton, Power, Persuasion, and Language; Bonte, Egalité et hiérarchie; Weir, Tribal Order, 3-4 with regard to Yemen; for an overall discussion see Gingrich, Prophet's Smile and Galactic Polities). Segmentary trees are, however, useful for illustrating the tree-like pattern of the structural organization of a tribe. 


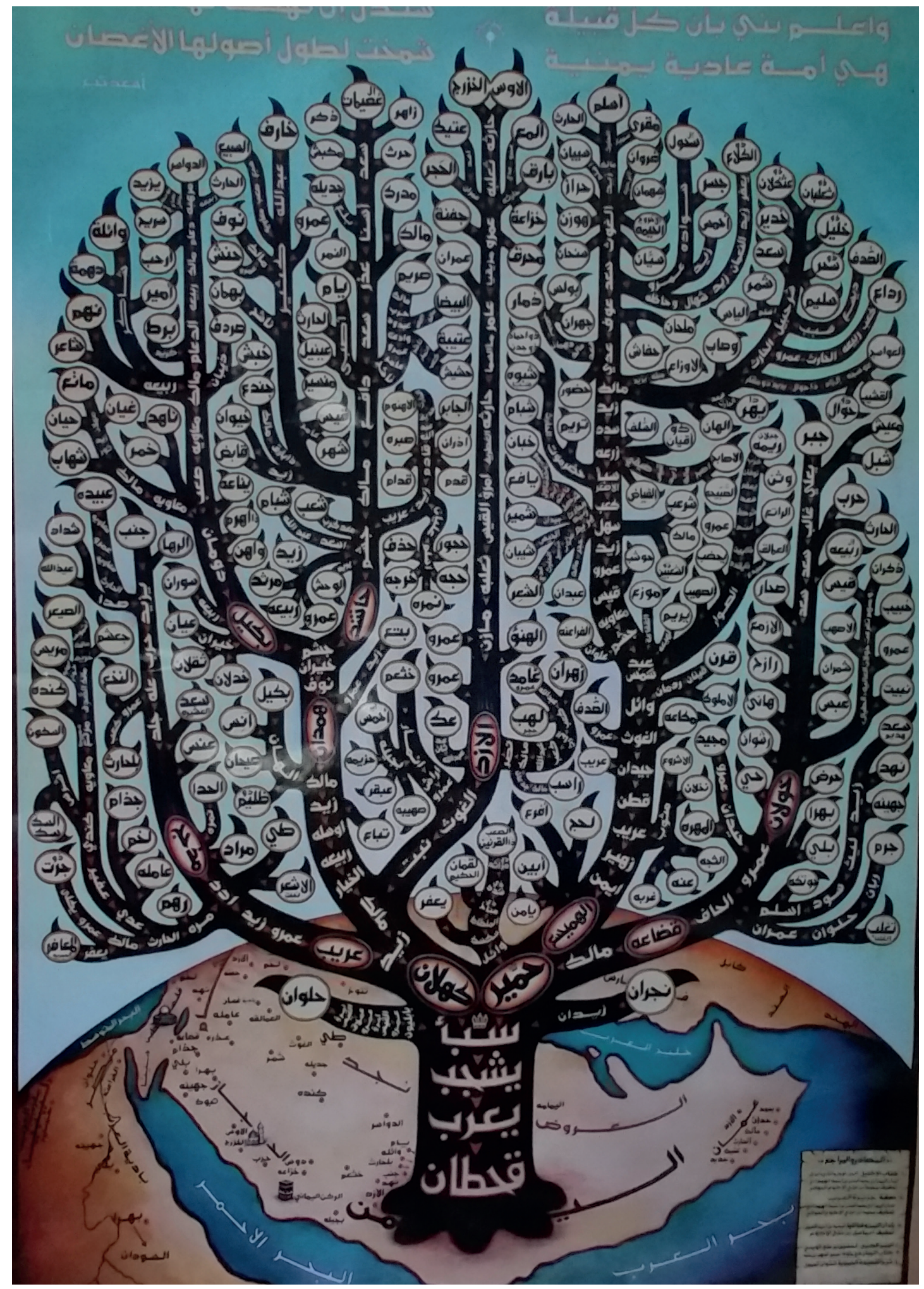

Fig. 1: Descendants of Qahtān according to al-Hamdānì (Illustration: Ministry of Culture, Yemen) 
Figure 1 depicts the progeny of Qahțān according to al-Hamdānī. Whereas a tree is often used to illustrate the genealogy of individuals and groups, Arab genealogists' terminology seldom refers to trees but focuses on the visual metaphor of the human skeleton and the human body as the common mode of representing kin groups, such as baț (pl. buțūn, lit. inner part, belly), fakhdh (pl. afkhädh, lit. tigh), fașìlah (pl. fașā ìl, lit. lower leg) etc. ${ }^{18} \mathrm{Al}-\mathrm{Hamdāni}$, too, introduces this terminology for tribal segments and subdivisions in al-Iklil, yet he rarely uses this taxonomy in his following elaborations. ${ }^{19} \mathrm{Al}$-Hamdāni’s terminology for describing tribal structures and affiliations is rather simple and largely confined to the term batn (in the sense of »tribal segment«) and banu (descent group). ${ }^{20}$ Figure 2 roughly visualizes the major descent lines of Qaḥțān.

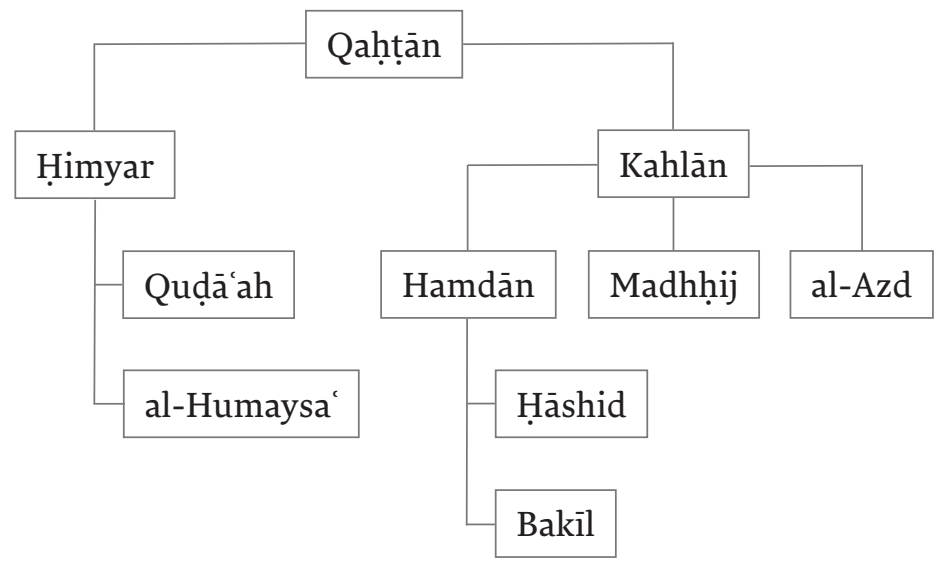

Fig.2: Progeny of Qahțān (simplified) according to al-Hamdānì

In the tenth volume of al-Iklīl, al-Hamdānì defines Shākir as a descendant of Bakil, his pedigree being Shākir b. Rabīáah b. Mālik b. Rabīaah b. al-Du’ām b. Mālik b. Mu'āwiyah b. Șa 'b b. Dawmān b. Bakìl; the brothers of Shākir are Nihm and Shā ir. ${ }^{21}$ Shākir begat Amìr, Duhmah, Wā'ilah, al-Ḥārith, and Yashkur. Figure 3 provides an overview of Shākir's descendants of the first four generations according to al-Hamdānī; in the time of al-Hamdānī some segments of Shākir already included far more generations as are shown in figure 3.

18 Varisco, Metaphors and Sacred History, 141-144.

19 Heiss, Tribale Selbstorganisation und Konfliktregelung, 94-95.

20 The same applies to the genealogical work of al-Kalbī; see Caskel, Gamharat an-nasab, 1, 23.

21 Al-Hamdānī, Iklìl 10, 237-244. 


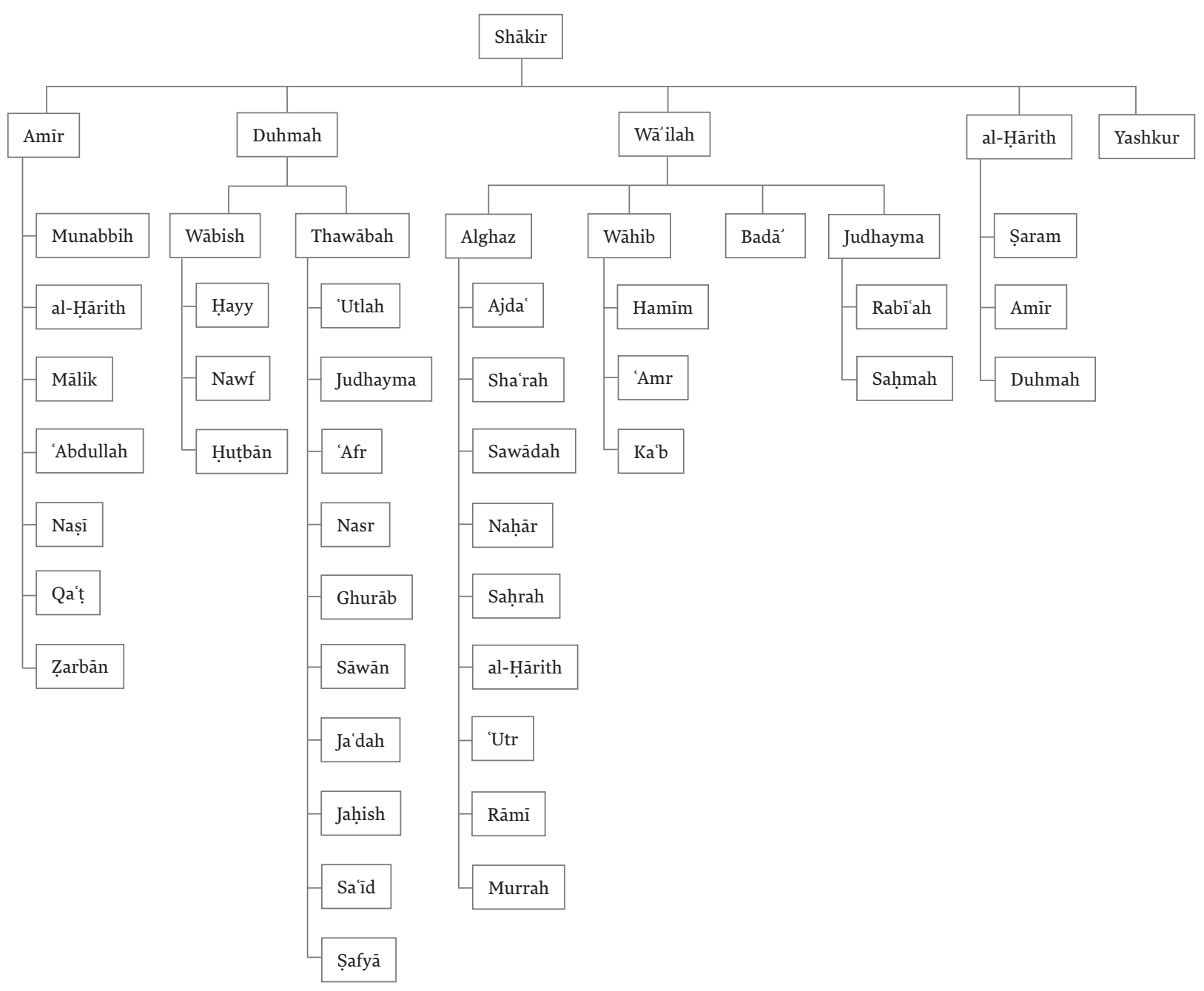

Fig. 3: Progeny of Shākir according to al-Hamdāni

Al-Hamdānī hands down the names of two sons of Duhmah b. Shākir: Wābish and Thawābah. Wābish begat Ḥayy, Nawf, and Ḥuṭbān, these buțūn were called Banū Wābish. Thawābah begat ten sons: 'Utlah, Judhaymah, 'Afr, Nasr, Ghurāb, Sāwān, Ja'dah, Jahish, Sa ìd and Șafyā. These ten sons became progenitors of descent groups retaining their progenitor's name: 'Afr begat the descent group of the 'Ufür (pl. of 'Afr), Nasr begat the Nusūr, Ghurāb begat the Ghurābah, Ja 'dah begat the Ja'ùd, and Safyā's offspring was called Safyāt, etc. Among the descendants of Ḥuṭbān b. Wābish (Banū Ḥuṭbān) al-Hamdānī mentions a certain Qays b. al-Arqat b. al-Ḥărith, who fought as a horseman (färis) in the front ranks of the Islamic conquerors against Persia in the battle of al-Qãdisiyyah (636 CE); in Yemen itself Duhmah did not play a significant role in the spread of Zaydism in the early medieval period. ${ }^{22} \mathrm{On}$ 'Amrū b. al-Ḥuṣayn b. al-Nu'mān of Banū Ḥuṭbān, al-Hamdānī tells us that he was the one who "forged the alliance between them and the Hamdān«. 
Al-Hamdāni reported that the Duhmah were in constant conflict with their sister tribe, the Wâ'ilah. In the tenth century, Wä ilah also formed a powerful group; the descendants of Wā'ilah were Alghaz, Wāhib (or Wahb), Badā', and Judhaymah: four buțūn. Wā'ilah was a prosperous tribe of which al-Hamdānī handed us a large amount of descendants: Alghaz begat Ajda', Sha rrah, Sawādah, Nahār, Saḥrah, al-Ḥārith, and 'Uțr (whose descendants were called al-'Uțūr), Rāmī (Banū Rām), Murrah, and (a second) al-Ḥāith. ${ }^{23}$ The al-'Uțūr changed their affiliations and adopted the genealogy of a much younger branch of Wá ilah, namely Judhaymah b. Zayd b. 'Umayrah b. Badā' b. Wă' ilah; al-Hamdānī does not mention any reasons for this process. Wāhib begat Hamìm, 'Amr, and Ka'b. Badā' begat 'Umayrah, Zayd, and al-Qașāṣ. Judhaymah begat Rabīah and Saḥmah. Al-Hamdāni mentions the names of many other buțun, some of them listed by name and praised for their honour (sharaf) and lordship (siyādah). Another person, namely Judhaymah b. Wä’ilah (jr.) b. Rabīah b. Judhaymah b. Wă ilah, went down in history as the man who "provoked the war with the Qudāah". In contrast to Duhmah, Wầ ilah often played a significant part in the politics of Zaydi affairs. ${ }^{24}$

The third son of Shākir was Amīr b. Shākir, who begat al-Ḥārith, Munabbih, Mālik, 'Abdullah, Naṣī, Qa'ṭ and Zarbān. Al-Hamdānī only passes down the descendants of al-Ḥāith b. Amìr and of Munabbih b. Amìr. Al-Ḥărith begat the Banū 'Abd, who further descended into the buțūn of Banū 'Uthmān, Banū Sayf, Banū Mālik, Banū Nimrah and Banū al-Dhawwād. Munabbih begat 'Āmir, and 'Āmir begat Akhnas, Nașr, Muhammad and 'Alī; the descendants of 'Āmir b. Munabbih were called the Banū 'Âmir b. Munabbih. ${ }^{25}$ In the ESA period, ${ }^{26}$ the Amir had been a large and powerful tribe.$^{27}$ In the tenth century, however, the Amir were obviously in decline; al-Hamdānī mentioned that by his time the Amīr were already an extinct part of Shākir (athrā Shākir). In most cases al-Hamdānī refers to Amìr in the same breath with Wă ilah. Indeed the Balad Shäkir (the territory of the Shākir) in parts corresponded to the pre-Islamic territory of the Amir. ${ }^{28}$

The main settlement area of the tribes of Shākir, consisting of Duhmah, Wā'ilah, Amìr and al-Hārith, were the western and northern parts of al-Jawf and the area between northern al-Jawf and the oasis of Najrān. Al-Jawf is the name of a vast territory whose boundaries are roughly defined to the west by the Barat plateau and to the south by the southern tributaries of Wādi Jawf. ${ }^{29}$ To the north and east the territory of al-Jawf extends into the Ghä it, as the southwestern fringe of the Rub' al- Khāli desert (literally, the Empty Quarter) was called at the time of al-Hamdānī. The Rub al-Khālì itself bore the name al-Dahnă'. The area of al-Jawf is dominated by three Wādīs draining into the Ghă iṭ: the contiguous Wādīs Khārid and Khabash, the Wādī Madhāb, which passes along its course in the Wādī Jawf, and the Wādī Khabb, all of them still bearing the same names as in al-Hamdāni’s time.

23 Among the sons of Alghaz, al-Hārith is mentioned twice.

24 Gochenour, Penetration of Zaydì Islam, 326.

25 At the time of al-Hamdānī, Munabbih was a common name that has been retained until today. A sub-tribe of the Shahrān is called Munabbih (Philby, Arabian Highlands, 119, 133), as well as a member tribe of the Khawlān b. 'Āmir (Khawlān Quḍāáah) in the highlands west of Șa dah city (Gingrich, Agrarkalender der Munebbih and Südwestarabische Sternenkalender).

26 The cultures of pre-Islamic South Arabia are attested for us almost exclusively by Epigraphic South Arabian (ESA) sources, hence the use of ESA hereinafter for the phenomena of these cultures.

27 Von Wissmann, Geschichte und Landeskunde von Alt-Südarabien, 80-206.

28 Von Wissmann, Geschichte und Landeskunde von Alt-Südarabien, 81.

29 The southern border of al-Jawf has no distinctive topographical features, but rather is defined by the border between the tribal territories of Bakil and Madhhij. 
The main settlement area of the tenth-century Duhmah was Jabal Barat, a steep-sided granite plateau (altitude about 2,00o meters) in the extreme west of al-Jawf, which roughly extends $40 \mathrm{~km}$ north to south and $60 \mathrm{~km}$ west to east. ${ }^{30}$ To its east Jabal Barat falls away into broken terrain before the desert begins in earnest. Originally Barat (as well as Kitāf and Nushūr, regions which belong to the settlement area of Wầilah) was a personal name: alHamdānī identifies Baraț, Kitāf and Nushūr as the sons of Karīm b. al-Duām al-Akbar, this group also being called Banū Karìm. ${ }^{31}$ The combination of place and genealogy by homonymy is not unusual: people or group names can also be place names and therefore have topographical significance. In al-Hamdāni’s accounts the toponyms are almost always derived from personal names, but less frequently vice versa. The personal names used as toponyms commonly refer to the residence of the eponymous group..$^{32}$ As usual when discussing tribal residents of his times, al-Hamdāni presents their affiliations as if - by a certain necessity going back to an eponymous ancestor, who "gave« his name to his descendants and, thereby, to their territory. However, Heiss has shown that in other regions, notably the Șa dah area further to the west, it may also have happened the other way round - i.e. a territorial unit arriving at such a level of coherence that an ancestral name had to be "found « for them that somehow related to the territory in question. Al-Hamdāni obviously was aware that this had happened on certain occasions, as when he refers to "Rāzihu as a territorial unit with only a vague indication of an eponymous ancestor. ${ }^{33}$

In the Sifah, in the chapter on the "Marvels of Yemen, which have no equal in other countries«, al-Hamdānī refers to Jabal Baraṭ:

Jabal Baraț. Its inhabitants are Duhmah of Shākir b. Bakil. Its summit is wide, it is considered a country. Its crops are irrigated by abundant rainfall and by irrigation systems, the nawà ih. One who was collecting the 'Alìd tithe told me about 5000 parts. [...] The summit of Barat is one of the healthiest and most pleasant parts of Yemen, and one with the most equable climate. It is situated between the Ghä it and the Najd. ${ }^{34}$

Al-'Alawi's description, as used by van Arendonk, shows that prior to the Islamic period the high plateau of Jabal Barat was a natural fortress beyond the control of external powers. ${ }^{35}$ At the time of Imām al-Hādì it could be accessed only by few paths. Thus al-Hādī had to be content with a punitive campaign to the northern foot of the Barat massif, after which Duhmah allegedly surrendered and promised to pay taxes.

Wă' ilah and Amìr inhabited closely aligned areas between Jabal Barat and the oasis of Najrān where their territory bordered on that of Yàm (another tribe of Hamdān stock dwelling in the Najrān region) in the north and east, partly overlapping with Yām's domains. ${ }^{36}$ Wă ilah were frequently in conflict with their northeastern neighbours, Yām, and their southern neighbours, Duhmah. ${ }^{37}$ The territory of Wă’ilah was defined by the Wãdīs Amlah, Ruhūu,

Al-Hamdānī, Șifah, 194-195. By Najd al-Hamdānī here means the central highlands of Yemen, not to be confused with the Najd of Saudi Arabia.

35 Van Arendonk, Opkomst van het Zaidietische Imamaat, 132-133.

36 Al-Hamdānī, Iklīl 10, 115.

37 Gochenour, Penetration of Zaydì Islam, 325. 
Kitāf, al-Aqīq, al-'Ațf (today: al-'Ațfayn) and al-Faqārah, all of them draining into the Ghā' iṭ, i.e. the Rub' al-Khālì. ${ }^{38}$ The Wādì Ḍadakh (at the confluence of its tributaries al-'Aṭ̂f and al-Faqārah) further to the east belonged to Amir. ${ }^{39}$

In the eighth volume of al-Iklìl, al-Hamdāni describes the famous pre-Islamic monuments of al-Jawf which originated from the time of the Kingdom of Ma in and most of which were already desolate and abandoned in the tenth century. ${ }^{40}$ These include the ancient cities of Ma în and Barāqish, both of which are located in the lower extremity of al-Jawf, facing each other at the foot of Jabal Haylān. Al-Hamdāni tells us of changing tribal occupations of these places. The ownership of Barāqish, for instance, changed from the hands of Hamdān to their rivals, Murād (a Madhhịj section). In other cases, such as the castle of Rawthān, settlements were abandoned due to infighting within the same tribe.

Al-Hamdānī praises al-Jawf, which today in large parts resembles a sea of shifting sand, as a fertile region, well irrigated and rich in trees, describing its climate as favourable and fruitful. ${ }^{41}$ He mentions "wonderful wells", including the deep Sarāqah well in lower al-Jawf, then belonging to Murād, whose water was "delicious and very sweet.$^{42}$ In the area of al-Razm he mentions "large fields that produce 20,000 dhahab, and even those that produce 30,000 qafiz « ${ }^{43}$. The inhabitants of al-Jawf were also noted as breeders of fine horses, a reputation reflected in Yemen's horse varieties listed in al-Hamdāni, such as al-khayl al-jawfi and alkhayl al-'ansi. ${ }^{44}$ Today certain tribal groups in al-Jawf still breed horses. ${ }^{45}$ Interestingly, these horses are ascribed genealogies of their own, and the histories of their bloodstock are intertwined with those of their owners. ${ }^{46}$

In addition to Shākir various other groups could be found in tenth-century al-Jawf: Arḥab, Nihm, Sufyān and Murhibah for instance, whose centres of settlement were actually elsewhere further to the west, but who were also present in al-Jawf. Notably Nihm controlled areas in central and southern al-Jawf. Madhhij were present mainly through Murād, at the time of al-Hamdāni, however, not at full strength. In the tenth century, Madhhij were already a loosely associated federation whose member tribes were living in widely separated areas, in 'Asir and Najrān, on the eastern slope, and on the southern plateau of the northern highlands ${ }^{47}$ Murād, the strongest Madhhij tribe in the early Islamic period, resided entirely

38 Al-Hamdānī, Șifah, 168.

39 Al-Hamdānī, Șifah, 168.

40 Al-Hamdānī, Iklìl 8: 105-114.

41 Al-Hamdānī, Șifah, 168.

42 Al-Hamdānī, Sifah, 200-201.

43 Al-Hamdānī, Șifah, 200.

44 Al-Hamdānī, Sifah, 200-201.

45 Brandt, Goldenes Zeitalter des Jawf.

46 Arabian tribes, who prize their horses dearly, do distinguish a number of lines and sublines of thoroughbred (așil) horses, although to label the use of these "family-names « as genealogy would be a massive exaggeration. However, the Ḥamdāni bloodstock of the aṣil Arab horses does not derive etymologically from Hamdān, and some historians argue that the Arab thoroughbred horse originally came from the north of Arabia. Arab legend, however, insists that the Arab horse came from Yemen, possibly taken in a ghazw (raid) by the Muteyr tribe (Peter Upton, pers. comm., July 2014). Also, al-Kalbi wrote about the Arab horse; his extant works include Al-Khayl (»Horses«), which contains short accounts of famous horses and poems on horses.

47 On processes of tribal fusion of Khawlān Quḍāah tribes with Madhhị segments in the Jīzān and 'Asīr regions, see Gingrich, Agrarkalender der Munebbih, 145-159; Südwestarabische Sternenkalender, 13-17; Konzepte und Perspektiven. 
in the deserts of the eastern slope. Murād had a high percentage of nomads in its numbers. ${ }^{48}$ Originally they were a Bedouin tribe in northeastern Yemen which dissolved around the sixth century as a socio-political unit, yet remained connected by the cult of Yaghüt. ${ }^{49}$

The coexistence of these groups seems to have been uneasy. Al-Hamdānì refers to a series of famines, droughts and plagues that presumably touched off tribal migrations. The struggle for land and resources forced many groups to leave their home areas and to intrude territories which then belonged to other tribes. Al-Jawf also witnessed constant strife and fighting between the then more sedentary Hamdān groups living there and Murād which comprised greater proportions of nomadic members. Murād and Hamdān were engaged in countless battles over supremacy and hegemony in al-Jawf. Undoubtedly these tensions had begun to seriously disrupt the agriculture that had been practiced in the once fertile lands of al-Jawf, and this disruption began to exert social pressures on the Hamdān tribes in al-Jawf to expand or perish. The antagonism between the tribes of Hamdān and Madhhij pre-dated the decisive battle between them that was fought at the time of the Prophet Muhammad in 2 H/622 CE in the area of al-Razm in lower al-Jawf, which al-Hamdāni praised for its fertility. The battle of al-Razm appears to have been the last time Madhhij functioned as a confederation. After they suffered a bitter defeat, Murād withdrew from al-Jawf to Ma rib and Ḥarīb and announced their conversion to Islam. ${ }^{50}$

\section{Contemporary Shäkir}

A glance at the tribal structure and settlement areas of the contemporary Shākir reveals that over the past thousand years they were subject to enormous changes. Duhmah became Dahm, and Shākir became the eponym of today's moieties Wā'ilah and Dahm. Amìr, al-Hārith and Yashkur, who already had a weak position in the tenth century, are extinct. ${ }^{51}$ The five fifths of historic Shākir have thus evolved into a system of moieties; a structural symmetry which can be found among many tribal societies of Yemen and beyond.

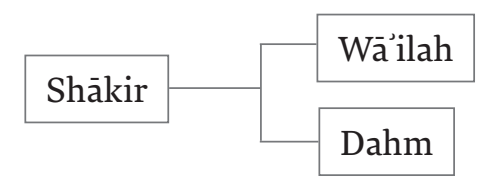

Fig. 4: Contemporary Shäkir

By the twenty-first century, Dahm consists of seven sevenths which are, again, organized in a system of moieties: Abnä' Nasr (lit. sons of Nasr, adj. nasrī) and Abnä' 'Amrū (adj. 'amrī). The nasrì tribes are Dhū Ghaylān, Āl Sālim, Āl Sulaymān and al-Muhāshimah. The 'amrī tribes comprise Āl 'Ammār, al-'Amālisah, and Banū Nawf. The genealogical nexuses Nasr and 'Amru are the points at which the genealogies of the contemporary segments of Dahm "meet«; they are purely genealogical constructs and do not express political alliances. ${ }^{52}$

48 Gochenour, Penetration of Zaydī Islam, 332; Caskel, Ğamharat an-nasab, 2. 61-65; Robin, Pénétration des Arabes, 74-75.

49 Caskel, Ğamharat an-nasab, 2, 64.

50 Caskel, Ğamharat an-nasab, 2. 62 n.4. For an overview of the references to Madhhij in the scientific literature, see Smith, Mad $\underline{h} \underline{h} \underline{i} \underline{j}$. On further details regarding al-Hamdānì's account of Madhhij see Mahoney, Political Construction of a Tribal Genealogy.

51 The tribal group called al-Ḥărith settling near Najrān, however, traces its descent to Madhhịj, see Heiss, Tribale Selbstorganisation und Konfliktregelung, 157-158; al-Ḥajrī, Majmu 'buldān, 1: 208.

52 In this respect, Dahm differ from Khawlān Quḍāáah whose moieties Yahāniyyah and Furūd simultaneously provide patterns for political alliances (Gingrich, Agrarkalender der Munebbih, 158-166; Brandt, Khawlän and Jumäah). 

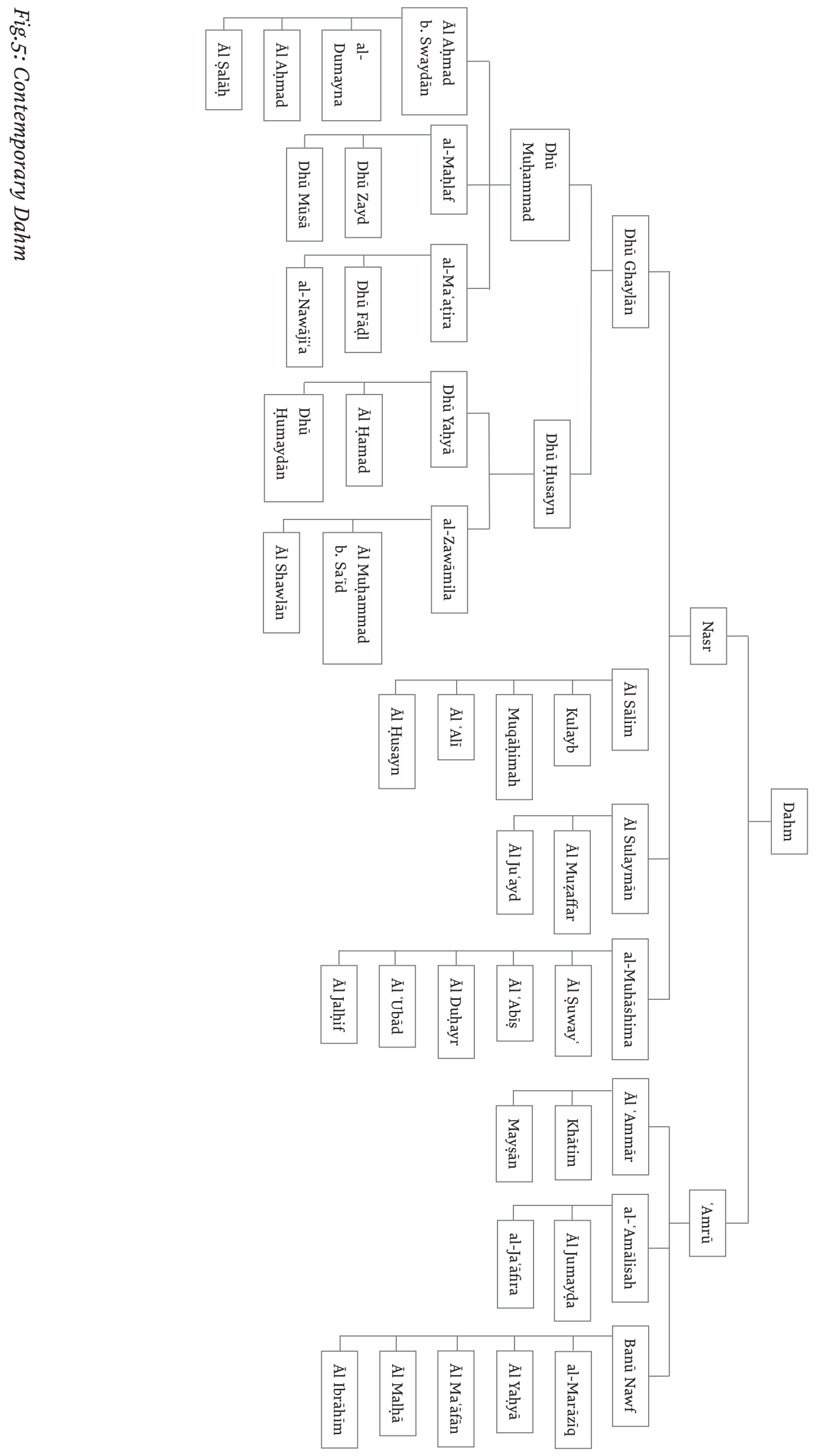
Duhmah's historical moieties, Wābish and Thawābah, are extinct. Thawābah may have sustained themselves in the name of the shaykhly lineage of Dhū Zayd b. al-Mahlaf of Dhū Muhammad, one of Dhū Ghaylān's moieties..$^{53}$ Nawf b. Wãbish b. Duhmah became the progenitor of Banū Nawf, one of the sevenths of contemporary Dahm. Huṭbān b. Wābish b. Duhmah is said to be still extant as a minor segment of Dhü Husayn, settling to the east of Barat in the Wādī Khabb region. ${ }^{54}$ According to tribal tradition another part of Huṭān emigrated from al-Jawf and fused with the genealogy of Murād (Madhhij). The descendants of 'Utlah b. Thawābah b. Duhmah are extant, too, appearing as al-'Utlāt among the sub-segments of Dhū Muḥammad..$^{55}$ Both Hut țān and 'Utlāt morphed from prominent senior descendants of Duhmah into tiny "junior " positions far down in the pedigree.

The numerous other groups referred to by al-Hamdāni in the tenth century are extinct. The reasons can be many. Famines, droughts and plagues may have caused extinction to the extent that whole lineages have petered out. Other groups may have moved elsewhere. The »deep fall« of Hut bān and al-'Utlāt from the superior levels of tribal segmentation into the minor segments of Dhū Husayn respectively Dhū Muhammad may be explained by the fact that lineage rumps of groups which are threatened with marginalization have the tendency to fuse with a collateral lineage (and in so doing fuse their resources with those of the adopting lineage), or for a numerically more powerful lineage group to take it over by force. This process has been observed in other tribal societies, such as the Cyrenaican Bedouin..$^{56}$ On the other hand, the rise of Nawf is an example for the foreshortening of genealogy, i.e. the process that certain names (here: Wābish) come to be omitted in the structure below the name of the founding ancestor. These processes of »telescoping " (an expression by Evans-Pritchard), i.e. the foreshortening or extension of genealogies, are characteristic genealogical features among many tribes, also observed among the Nuer and the Cyrenaican Bedouin..$^{57}$

In addition to Banū Nawf, six other midsize segments of Dahm have emerged in the last millennium: Dhū Ghaylān, Āl Sulaymān, Āl 'Ammār, al-'Amālisah, Āl Sālim, and al-Mahāshimah, each of them linked with the genealogy of Dahm through the eponym of its respective moiety (Nasr or 'Amrū). Dhū Ghaylān are reckoned sons of Muhammad b. Sha'bān b. Nasr b. 'Amrū b. Dahm, al-Mahāshimah are reckoned sons of Mas'ūd b. Nasr b. Dahm, Āl 'Ammār are reckoned sons of 'Amrū b. Dahm, etc.

Today the best known and politically most important segment of Dahm, Dhū Ghaylān with its moieties Dhū Husayn and Dhū Muhammad, emerged only after the tenth century. Supporting evidence for their formation is thin; the names Dhū Muhammad and Dhū Ḥusayn seem not to be attested until about $1600 \mathrm{CE} . .^{8}$ Local oral tradition suggests a formation in late medieval times and identifies Ghaylān as a wartime leader of Dahm, who united a part of his tribe in a period of acute conflict with their sister tribe and rival Wä' ilah, forming a stable group which was then referred to as Dhū Ghaylān. In this way these events (i.e. a particular episode of the eternal conflict between Dahm and Wầ ilah) were transformed in both legend and genealogy: genealogy has taken over the function of historiography. Also this principle

53 Dresch, Tribes, Government, and History, 90.

54 Al-Hajrī, Majmu 'buldān, 1. 114.

55 Al-Hajrì, Majmu’ buldān, 2. 575.

56 Peters, Proliferation.

57 Evans-Pritchard, Nuer, 198-199; Peters, Proliferation.

58 Dresch, Tribes, Government, and History, 324-325. 
of "selective memory « is common practice in regard to tribal genealogies, because, as Caskel put it, the "youngsters" had to know who among their ancestors and relatives had led the major wars and who had been killed by whom, and whose death had to be avenged on whom. ${ }^{59}$ In this way many ancient heroes and leaders have gone down in the genealogies of their tribes. The addition of certain ancestors is often associated with the omission of others. Bonte has called this basic method of genealogical manipulation »selective amnesia «, i.e. the deliberate omission of less than prestigious ancestors from one's genealogy and a careful selection of the most illustrious forebears to include in the genealogy, a common manoeuvre that is aimed at maximizing the social prestige that can be accumulated from real or putative descent. $^{60}$

Because of its inherent contradictions and unclear affiliations, it is always a kind of gamble to fix a tribal structure in writing. The structure of contemporary Dahm features many ambiguities. For instance, the precise segmentary status of Ḥuṭbān and al-'Utlāt as components of contemporary Dhū Husayn respective Dhū Muhammad has proven to be rather elusive. Another example is al-Ma āțirah. The position and lineage of al-Ma'ātirah is disputed and it is almost impossible to reach an agreed upon lineage and structure for al-Ma ātirah. Al-Ḥajrī and al-Maqhafí trace the tribe through Dhū Ghaylān and Dhū Muhammad. ${ }^{61}$ Dresch argues that al-Ma ătirah functions as a "sixth fifth " of Dhū Muhammad. ${ }^{62}$ One of my fieldwork sources told me that al-Ma āțirah descends directly from Dhū Ghaylān, thus speaking of themselves as a »brother" of Dhū Muhammad and Dhū Husayn. Considered from the genealogical point of view, 'Iyāl Surayḥ (lit. children of Surayḥ) also belong to Dhū Ghaylān, a tribe settling east of 'Amrān city and normally reckoned a constituent tribe of the Bakil confederation, and thus omitted in figure 5. 'Iyāl Surayḥ are descendants of Surayḥ b. Ghaylān b. Nasr b. Dahm, the "brothers" of Surayḥ are thus Dhū Ḥusayn and Dhū Muhammad in Ghaylān b. Nasr b. Dahm.

The remaining segments of present-day Dahm are not mentioned by al-Hamdānī; they were either not yet existent or were added later to Dahm from other, dissolving Shākir genealogies. Yet no evidence could be found (which does not mean that it does not exist) for descendants of the now defunct Amìr and al-Ḥanrith lineages having fused with the genealogy of other branches of Dahm, a process that regularly took place among other tribes of Qahțānī descent. ${ }^{63}$ Certainly, some of the other groups of Hamdān pedigree who already lived during the tenth century in al-Jawf (Nihm, Arḥab, Sufyān, Murhibah, etc.) morphed into the genealogy of Dahm. As Dresch pointed out, among Dahm one finds sections with the names of tribes elsewhere. ${ }^{64} \mathrm{Al}-\mathrm{Hudhayl}$, a conspicuous section name in Sufyān, recurs in Dhū Muhammad; Sufyān's Abnā’ al-Marzūq echo al-Marāzīq of Nawf, etc. In both Dhū Muhammad and Dhū Husayn one finds many distinctive family or section names which occur in other tribes.

59 Caskel, Gamharat an-nasab, 1: 35 .

60 Bonte, Egalité et hiérarchie.

61 Al-Ḥajrī, Majmu 'buldān, 1: 111-112; and al-Maqhafi, Mausū'at al- ’alqāb, 1566-1567.

62 Dresch, Rules of Barat, 29-33.

63 Brandt, Khawlān and Jumāàh.

64 Dresch, Rules of Barat, 57. 
In addition, a considerable part of the groups that do constitute contemporary Dahm can look back on an origin from outside al-Jawf. Local oral tradition has it that numerous tribal groups from Haḍramawt, Shabwah, the inner-Arab Najd and 'Asir (the latter two today situated in Saudi-Arabia) have migrated into al-Jawf. As locals put it, Dahm do not descend from (la yanhadir min) a single descent, but go back to more than one tribe. In itself, this pattern of a tribal composite group of plural origins already occurred in al-Hamdānī's times ${ }^{65}$; the various tribal groups of composite origins were rather the norm than the exception, and obviously in the twenty-first century this still is the case.

These claims are sometimes more, sometimes less precise. To give a few examples: Āl alShāyif of Dhū Ḥusayn immigrated from Bīshah ('Asīr), Āl al-'Ansī of Dhū Muḥammad originate from 'Ans b. Madhḥij, and Āl Ḥamad of Dhū Ḥusayn immigrated from Wādī Ṭuwayq in today's Saudi Arabia, a large Wādī more or less part of the wider neighbourhood of Qaryat al-Fāw, the historic capital of Kinda and Madhhij. ${ }^{66}$ Around Baraț it is said that there are numerous families of Dhū Muhammad and Dhū Ḥusayn who originally came from Najrān, 'Asir, and other regions, but there seems no agreement on exactly who they are or when they came. ${ }^{67}$ All of them are now united under the umbrella of the Shäkir genealogy where they occupy a well-founded, albeit fictional place.

Also Hamdān al-Jawf and its eight tribes al-Faqmān, Āl Kathīr, Āl Ḥadījān, al-Ḥirjah, Āl 'Abīd, al-Khawāțirah, Âl Zāmil, and al-Shujn, who are now installed in the lower Jawf around al-Jawf's modern main administrative centre al-Hazm, is often identified as a tribe of Dahm. The members of the Hamdān al-Jawf tribe, however, see themselves as an independent tribe of Hamdān pedigree which neither descends from Dahm nor from Shākir, and moreover, neither belongs to Bakil nor to Ḥāshid. The genealogy of Dahm »meets with Hamdān al-Jawf in Hamdān b. Zayd«, as informants put it. Yet by territorial proximity and alliance policy Hamdān al-Jawf is today close to Bakīl and in particular to Dahm b. Shākir. According to local sources from this very group Hamdān al-Jawf, too, is a gathering, a conglomerate of groups with and without Hamdān genealogy. Many elements of Hamdān al-Jawf trace their descent to regions further east. The descent of Āl al-Shujn, for instance, goes back ( $t a$ 'ù ilä) to the Hadramī Nahd tribe. The Āl 'Alì and Āl Șālị̣ of al- Ḥirjah have roots in Shabwah, and the Āl al-Makkī of Āl Zāmil originate from Murād.

Also the genealogy and tribal structure of Dahm's sister tribe Wà ilah have undergone radical transformations and resemble only remotely those of the tenth century. The historic fourths of tenth-century Wā' ilah (Alghaz, Wāhib, Badā' and Judhayma) have morphed into moieties, namely Rijāl 'Ulah (adj. 'alhānì, lit. descendants of 'Alhān) and al-Sha rāt (adj. sha 'rì). The linages of Badā' b. Wà'ilah and Wāhib b. Wā'ilah have petered out. The other two eponyms, Judhaymah and Alghaz, have been eradicated by "selective amnesia", yet oral tradition traces the descent of Rijāl 'Ulah through the lineage 'Alhān b. Wä' ilah b. Rabī'ah b. Judhaymah b. Wă'ilah b. Shākir, thus linking them with Judhaymah b. Wä ilah, one of the fourths of historic Wā' ilah. Al-Sha' răt, Wà' ilah's other moiety, are the collective form of historic Sha'rah, the son of Alghaz, and indeed the contemporary al-Sha'rāt trace their descent though al-Sha rah b. Alghaz b. Wā’ ilah b. Shākir.

65 Heiss, Tribale Selbstorganisation und Konfliktregelung, 125-164.

66 The Kinda are a tribe of South Arabian origin. Some Kinda groups migrated around the seventh century CE from Hadramawt to the western part of Yemen, Central and North Arabia, and Egypt; cf. Olinder, Kings of Kinda; Caskel, Ğamharat an-nasab, 1. 33; 2. 47-53; Bamyeh, Nomads of Pre-Islamic Arabia. On Qaryat al-Fāw see al-Ansari, Qaryat al-Faw.

67 Dresch, Rules of Barat, 57. 


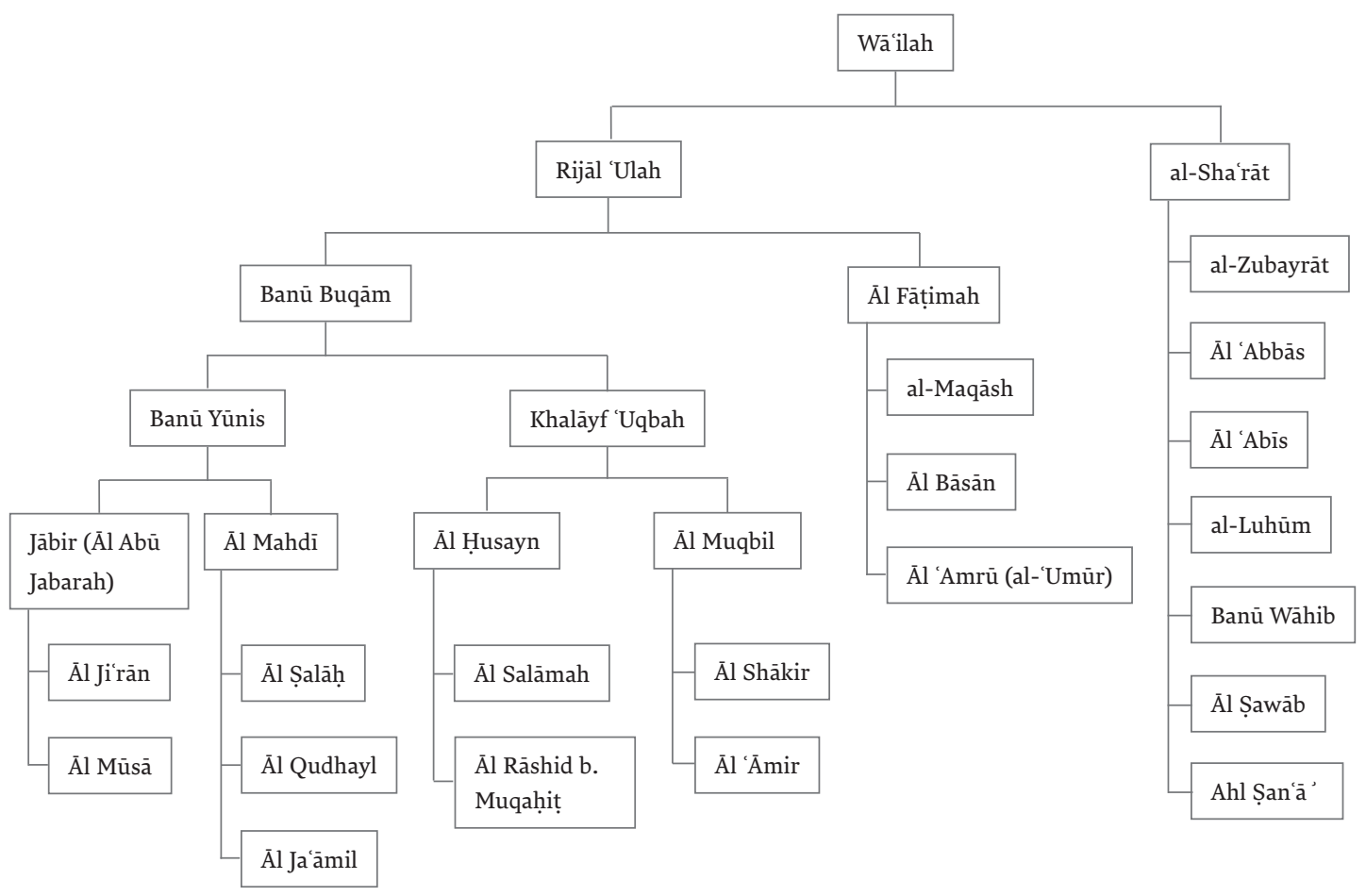

Fig. 6: Contemporary Wāilah (simplified)

All branches shown in this structure further subdivide extensively. Local sources among Wä' ilah indicate that the descent groups Rijāl 'Ulah and Sha rāt are the result of intra-tribal fusions and fissions. Banū Wāhib for instance, a segment of the contemporary Sha'rāt, are identical with Banū Wāhib of historical Wă ilah, Wāhib thus actually being the uncle of Shā ir and not his son. These shifting affiliations are not unusual; Arab genealogies feature many examples of these adjustments and re-alignments of ancestors and tribal divisions for the sake of changed alliances (taḥälifät) within a tribe. ${ }^{68}$

Also the structure of contemporary Wä ilah offers plenty of surprises. For instance, among Wă ilah one can find several exceptions to the rule that the agnatic lines of descent are never interrupted by women. However, one of the moieties of Rijajl 'Ulah bears the name of a woman: Āl Fāțimah. Oral tradition has it that Fățimah was one of Buqām's two wives. The sons of Buqām and his first wife formed the Banū Buqām segment. The sons of Buqām and his second wife Fāțimah (Maqāsh, Bāsān, 'Amrū) became a separate lineage called the Banū Fāțimah or Āl Fāțimah.

The principle of maternal ancestry appears several more times among Wā̉ ilah. Āl Dāyil b. Fayṣal of Âl Abū Jabārah in the extreme east of Wă ilah territory are one of Wă ilah's senior shaykhly lineages. They belong to the supreme judicial authorities (sing. maräghah) of Bakil in customary law ( $u r f$ ). ${ }^{69}$ The incumbent shaykh of this lineage does not only bear the title Ibn Dāyil b. Fayṣal, but also the byname (laqb) Ibn al-Qãyfiyyah. Oral tradition identifies

68 Caskel, Ğamharat an-nasab, 1. 69; Brandt, Khawlän and Jumāàh.

69 Brandt, Inhabiting Tribal Structures. 
Qāyfiyyah as a daughter of a sharif $7^{70}$ from al-Jawf who had married into the Dayyil b. Faysal shaykhly lineage. According to tradition, the father of Qayyfiyyah had been killed by the neighbouring Yām tribe, with which Wă ilah historically maintain as precarious relations as with Dahm.

Interestingly, some tribal sources also reckon the ancient eponyms Duhmah and Wâ ilah having been women. In contrast, al-Hamdānī refers to them as men (i.e. sons of Shākir). ${ }^{71}$ According to oral tradition, Duhmah and Wă ilah were the wives of Shäkir. In fact, the masculine form Wă il appears frequently in al-Hamdānī's genealogical compendium, whereas the feminine form Wă ilah only appears in the case of Shākir. Caskel points out that these ancestral women can be found almost exclusively at higher levels of genealogies, where they barely could be known personally to their descendants. ${ }^{72}$ Such ancestral women usually come from other tribes, because »open" marriage policy towards other groups and tribes and alliances with other tribes were often cemented by marriage, causing considerable growth in the size of a tribe. ${ }^{73}$ The woman's name is retained in the genealogy in order to strengthen solidarity with the other tribe. If, then, half-brother differentiation or full sibling unity is to be shown genealogically, the obvious way in which this can be done is to use a maternal name in the genealogy. This can be effected by clustering the groups around the name of the mother, thereby making the two clusters of groups stand in the relationship of paternal half-brothers. Thus the appearance of ancestresses in nasab reinforces alliances with other tribes while simultaneously it does not deny patrilineality; on the contrary, it serves in a sense to reinforce it.

Today the Balad Shäkir is both far larger and more homogeneous than in the tenth century. Wă ilah have expanded to include also the former territory of Amīr. Wādī Dadakh, which formerly belonged to Amīr, is now called Wādī Āl Abū Jabārah and inhabited by Wā' ilah's homonymous segment Āl Abū Jabārah of Rijāl 'Ulah. The main settlement area of Dahm has expanded enormously and comprises now the largest part of al-Jawf. Beginning in al-Jawf's extreme northwest area at the Barat plateau, a combination of Dhū Muhammad and closely aligned al-Ma ățirah constitutes the majority of Baraț's residents; another enclave of Dhū Muhammad can be found in lower al-Jawf within the settlement area of Dhü Husayn. The territory of Dhū Husayn is enormous and stretches from the border line with adjoining villages of Dhū Muhammad at Barat to the southern edge of Wādī al-Jawf and an indeterminate distance eastward into the vast space of the Empty Quarter. Dresch notes that further eastward still, Dahm make extravagant claims about what their territory might cover and if one asks where the furthest borders of Dahm are, then one is sometimes told Qatar. ${ }^{74}$ More real-

70 I.e. a member of the Ashräf tribe. The Ashräf tribe claims direct descent from the Prophet Muhammad. Despite maintaining a degree of independence from the tribal environment within which they live, the Âl Ashrāf nonetheless maintain many of the structural characteristics of a conventional tribe (vom Bruck, Islam, Memory, and Morality in Yemen, 141-142).

71 Many other names referred to by al-Hamdānī in regard to Wā' ilah's medieval tribal structure, such as Nawf, Sha rah, Sawādah, Nahāar, Saḥrah, etc., could also be women.

72 Caskel, Ğamharat an-nasab, 1. 52-53. See also Peters, Proliferation, who observed that the Bedouin of Cyrenaica claim that they are all descendants of a unique ancestress. In this case female names can be used to show a greater notion of cohesion than the mere use of male names, and the significance of a female name placed at the apex of the Cyrenaican genealogy is that it is the symbol of full-brother unity at the highest political level.

73 Peters, Proliferation; Bonte, Egalité et hiérarchie; Landau-Tasseron, Status of Allies.

74 Dresch, Rules of Barat, 43. 
istically, the meeting point of Dahm as a whole with Âl Murrah (the Yām section) and Șay'ar (a Saudi desert tribe of Kinda pedigree) is near Sharürah, just north of today's Saudi-Yemeni border at the longitude of central Hadramawt.

Banū Nawf reside in a vast area which begins only a few kilometres east of al-Hazm, al-Jawf's main commercial and administrative centre, and covers the entire southeastern (lower Khabb wa al-Sha f area) and eastern al-Jawf. Al-Mahāshimah controls a territory in the northern Khabb wa al-Sha'f area near Yemen's border with Saudi Arabia. The settlement areas of the four midsize tribes Āl 'Ammār, Âl Sālim, Âl Sulaymān and Āl 'Amālisah are located in eastern Șa'dah governorate north of the Baraṭ plateau. Āl 'Ammār and Âl Sālim are two smaller enclaves a few miles south and southeast of Șa dah city in the Șa dah basin which is dominated by the Sahāăr tribe of the Khawlān b. 'Āmir confederation (Khawlān Quḍāáah). Al-'Amālisah and Āl Sulaymān form a buffer zone north and northeast of Jabal Barat between the territory of Dhū Muhammad and Wä ilah.

In the tenth century, Sufyān had a strong presence in northern al-Jawf $\mathrm{f}^{75}$ but were then displaced due to a conflict with Dhū Husayn. Tribal oral tradition has it that "once upon a time" (fī yawm min al-ayyām) Dhū Ḥusayn abducted a shepherdess of Sufyān. In turn Sufyān, led by Ḥaydar, the eponymous ancestor of today's shaykhly lineage of Sufyān's Ruhm moiety, attacked Dhū Ḥusayn. In the ensuing battles, Sufyān killed 112 of Dhū Ḥusayn, whereas Dhū Ḥusayn killed seventy of Sufyān, among them Sufyān's wartime leader Ḥaydar. Thus the death of forty-two victims still had to be avenged by Dhü Husayn on Sufyān (wa min hunā' baqiya li-Dhü Husayn ithnān wa 'arba ün qatìl tha'r ind Sufyān). Sufyān then withdrew from northern al-Jawf and entrenched themselves, so that none of them would be killed in the name of revenge, and Dhū Husayn took the territory of Sufyān in al-Jawf as material compensation for the unavenged death of forty-two of their members. ${ }^{76}$

Today only a few other groups outside the genealogy of Shākir are dwelling in al-Jawf. The largest are Hamdān al-Jawf, who are centred around al-Hazm and are closely associated with Dahm. In addition two smaller enclaves of the Ashräf tribe are settling in lower-al Jawf, their main settlement area being located in the Ma rib area further to the south.

These territorial demarcations should not detract from the fact that it is not always possible to define the territories of tribal groups in al-Jawf. As one of few tribes in Yemen, Dahm today comprises a significant proportion of nomadic members who have a different system of territories and borders in comparison to the sedentary tribes further to the west, i.e. their tribal territories are not made up of exhaustive and exclusive section-territories. In many places in al-Jawf a distinction between sedentary and nomadic groups is impossible. Steffen in his survey of al-Jawf in the 1970 s encountered fully sedentary farmers, permanently migrating cattle breeders (Bedouins) and all kinds of organizational forms between these two elementary life styles. ${ }^{77}$ Even within one single tribal segment there were different divisions, some of which were fully settled, some semi-Bedouin and other Bedouin. According to Steffen, the average percentage of Bedouins in al-Jawf was $25 \%$, in some areas such as the Wādì Khabb 40\%, among Dhū Zayd of Dhū Muhammad even $80 \%$. No statistics are available for

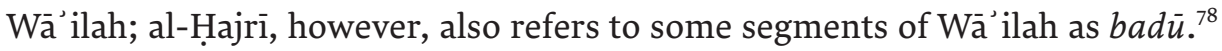

75 Al-Hamdānī, Șifah, 110.

76 Boundary disputes between the Sufyān and segments of Dhū Ghaylān are still active; see Dresch, Tribes, Government, and History, 259, 321, 338.

77 Steffen, Yemen, 2. 121-124, 198.

78 Al-Ḥajrī, Majmu' buldān, 2. 477. 


\section{Entanglement and rejection}

The formative process of Shākir mirrors the genealogists' findings that it is not always descent that shapes the political and territorial relations of tribes and tribal segments, and that frequently descent and genealogy are rather the vocabulary through which such relations are expressed, regardless of, and often in contradiction to, known biological facts. Bonte has called these types of non-genealogical solidarities prevalent in tribal communities which are expressed in genealogical terms "parenté élective «. ${ }^{79}$ Heiss has further analysed the ways in which these forms of genealogical reasoning functioned according to al-Hamdānī, how they could be manipulated, altered or elaborated according to new constellations, and how they served specific needs and interests. ${ }^{80}$

In addition to this quite common feature, however, the formative process of the Shàkir tribe features two special and interrelated characteristics. Firstly, the enormous changes to which parts of Shākir's tribal structure, genealogy and territory have been subjected since the tenth century, and secondly, the notably large number of immigrant groups who fused with the genealogy of Shākir (especially Dahm).

The relation between these phenomena can better be understood if we look back beyond the tenth century, upon the history of Yemen's pre-Islamic kingdoms. The society of the South Arabian kingdoms of the ESA period differs in important respects from that of the tenth century. The evidence from the inscriptions of the pre-Islamic South Arabian societies suggests that descent and lineage were of little importance to the bearers of the ESA cultures: its communities were first and foremost territorial units and farming populations in which long elaborate pedigrees were unknown..$^{81}$ Dostal outlines a »dynastic « source of genealogical unilineality as rooted in pre-Islamic South Arabian rulers' dynastic ambitions towards legitimizing continuity. ${ }^{82}$ According to Dostal, the evolution of patrilineal genealogy takes place at the same time as the consolidation and development of institutions of centralized governance during the last centuries before the Common Era, and thus would appear to be an endogenous process. Dostal argues also that the spread of monotheistic religions may have played its part in the development of such a high level of patrilineality, as their norms are based on the concept of patrilineality which helped to consolidate that level of patrilineal ordering of kinship which had already been attained.

Others, in contrast, assume that the system of patrilineal genealogical representation has been imported by nomadic "Arabs" to Yemen: intrusive tribes from inner-Arabia and the outskirts of the vast Rub al-Khāli desert, to whose onslaught the South Arabian kingdoms were increasingly exposed since the last centuries before the Common Era. ${ }^{83}$ Initially the ancient South Arabian kingdoms could absorb and exploit the Arabs' boldness and pugnacity for their own purposes; from the middle of the first millennium $\mathrm{CE}$, however, the intrusive Arabs deployed a force that contributed to the decline of the already ailing South Arabian kingdoms. ${ }^{84}$ These intrusive Arabs may have brought with them the nasab tradition which

79 Bonte, Egalité et hiérarchie.

80 Heiss, Tribale Selbstorganisation und Konfliktregelung.

81 Beeston, Kingship in Ancient South Arabia, 258; Robin, Hautes-terres du Nord-Yémen, 1. 71-73; Höfner, Beduinen, 62.

82 Dostal, Transition from Cognatic to Unlinear Descent Systems, 47-62.

83 Höfner, Beduinen, 60-68; Caskel, Gamharat an-nasab, 1. 20; Robin, Pénétration des Arabes.

84 Robin, Pénétration des Arabes. 
had been previously unknown in this form in Yemen, and which was gradually taken over, in varying degrees, by the domestic population. Thus between the ESA period and that of alHamdānī a major change in social organization (or "culture shift", as Beeston called it) had taken place, the shift from sha $b$ to qabilah, a shift from an idiom of territory to one of shared descent. This more or less continuous invasion resulted in »bedouinized " parts ('arab) and non-»bedouinized « parts (ahmūr, i.e. »Himyarites") of Hamdān; as far back as the sixth century Shākir were, together with Ḥajūr, Yām, Wādi a'ah, Dālān, 'Udhar, Khārif, Arḥab, Murhibah and Nihm, reckoned 'arab. ${ }^{85}$

This uniform nasab tradition, however it was brought about, did not comply with many of the components of Yemen's population. In many regions of Yemen territoriality remained a basic principle since large parts of Yemen's tribal system, as compared with many others in the Middle East, remained characterized by an apparent longevity of toponyms and territorial boundaries as opposed to the respective resident population, many of them emigrated from or migrated into these territories quite frequently. ${ }^{86}$

We can, however, perceive a noticeable difference between the sedentary tribes of central and western Yemen and tribes of al-Jawf. The eastern location of Shäkir at the fringe of the Rub' al-Khâli desert and the gateway of ancient trade and travel routes between South and North Arabia makes the record of immigration among them more relevant than among groups further to the west. The considerable number of immigrant groups that have joined Shākir since the tenth century, in particular Dahm, suggests that the historic movement that drove nomadic desert tribes to al-Jawf did not stop in the tenth century but rather continued long after it. The genealogical and territorial changes we have observed among Shākir tribes were thus in parts the result of internal developments and regroupings (according to Dresch's "Rubik's cube " pattern) and in parts the consequence of the continuous penetration of external groups from elsewhere into al-Jawf and other areas at the fringe of the Rub alKhālì, a process similar to that which Dussaud has carefully analysed on the Syrian side. ${ }^{87}$

Thus al-Jawf seems to indicate a specific case among a greater diversity of regional variations, which also include fewer records of such immigration stories and territorial changes. The impact of immigrants on the tribal society of Shäkir and their genealogy, structure and territoriality appears to have been greater than on the tribes to the more westerly areas in the central, rugged highlands of Yemen. The rugged terrain of the interior highlands of Yemen has been a factor contributing to the stability of the tribal areas. Wilson argues in his exploration of Hāshid and Bakil in the central parts of the highland plateau - roughly between the city of Sana'a in the south and Khaywān in the north - that substantial traces of the pre-Islamic tribal order continued to exist well into the Islamic period, and also over the past ten centuries Wilson found little evidence of major tribal movements in that area; his overwhelming impression was one of remarkable continuity and minimal change, even if tribal affiliations have from time to time altered or developed..$^{88}$ Dresch, too, stresses the importance of structural continuity and territorial fixity for most of the tribes of Hamdān in the central highlands; yet he also noted the exception to this rule in al-Jawf. ${ }^{89}$ In other areas of the cen-

85 Caskel, Ğamharat an-nasab, 2. 47.

86 Dresch, Tribes of Hāashid-wa-Bakīl, 9-10; Weir, Tribal Order, 2; Gingrich, Multiple Histories.

87 Dussaud, Pénétration des Arabes.

88 Wilson, Al-Hamdānī's Description of Hāàhid and Bakīl, 96.

89 Dresch, Hāshid-wa-Bakīl and Tribes, Government, and History, 324. 
tral highlands, such as among the member tribes of the Khawlān b. 'Āmir (Khawlān Quḍāah) confederation, the changes between the tenth and the twenty-first centuries can often also be explained as results of intra-tribal fusions and fissions, ${ }^{90}$ although here also were larger movements of tribes and tribal segments, movements that have left their traces in the collective memory and the genealogies of the tribes. ${ }^{91}$ This explains why many present day tribes of the central highlands of Yemen claim always to have been where they now are. In the central highlands there is little rhetoric whatsoever of conquest or major displacement, and disputes over borders, for example, are mostly spoken of as a "renewal « of lines that already existed..$^{92}$ In short, even during al-Hamdāni's time and throughout the centuries that have passed since then, in these central areas a remarkable territorial continuity and stasis prevails that is contrasted by stronger elements of residential discontinuity and mobility. ${ }^{93}$

Certainly in the way that the affiliations of tribal groups changed hands one also can see other factors, for example politics (in fact, struggles for power) intruding on the formal alignments of tribal groups. At the time of al-Hamdāni parts of Yemen were dominated by a number of rulers and chieftains who had risen to power as 'Abbāsid control over Yemen had diminished. In the Șa 'dah area the first Zaydī imām, al-Hādì ilā al-Ḥaqq Yahyā b. al-Ḥusayn founded the Zaydi dawlah and a dynasty which was to rule in parts of Yemen until 1962. In other areas, in which the authority of these dynastic rulers was not felt, tribal leaders held sway. ${ }^{94}$ In the decades and centuries after al-Hamdāni numerous dynasties throughout Yemen gained power, competed with each other and controlled dominions of varying size: the Ziyādids, the Yúfirids, the Șulayḥids, the Hamdānid Sultans, the Mahdīds, the Ayyūbìds, Rasūlids, Țāhīìids, etc. ${ }^{95}$ Historically Yemen witnessed Abyssinian, Persian and Ottoman invasions and finally the expansion of Wahhābis at its northern borders. Yet many of these political currents and struggles certainly had a greater impact on the central parts of Yemen than on the somewhat "peripheral « area of al-Jawf, since for long periods of history al-Jawf was in some ways remote and politically closer to the Najrān oasis and valley, a region of great historical importance, than to the central parts of Yemen. ${ }^{96}$ It would, however, hardly be surprising if parts of al-Jawf also became caught up eventually in the currents and counter-currents of political competition, and if the interventions of these powers and the resulting conflicts, alliances and oppositions contributed to further reshuffles among tribal categories in al-Jawf.

90 Gingrich, Agrarkalender der Munebbih, 145-158; Heiss, Tribale Selbstorganisation und Konfliktregelung; Brandt, Khawlān and Jumāàh.

91 For instance, the migration of a part of Khawlān from the Șirwāh area to the Șa dah basin (Heiss, Landnahme der Hawlän and Tribale Selbstorganisation und Konfliktregelung, 107-122; Brandt, Khawlän and Jumäah) and the migration of Madhhiij groups to Jīzān and 'Asīr (Gingrich, Agrarkalender der Munebbih, 145-159, Südwestarabische Sternenkalender, 13-17, and Konzepte und Perspektiven). Also the contemporary Rāziḥ of Khawlān Quḍāah imagine themselves as being a land of people descended mostly from immigrants seeking work in agriculture or trade in the fertile Rāzih region (Weir, Tribal Order, 52-53), a conception which may, however, also constitute a distant echo of the Khawlān's grand migration from Șirwāḥ to Șa ‘dah during the pre-Islamic Period.

92 Dresch, Tribes of Hāshid-wa-Bakìl, 11.

93 Gingrich, Multiple Histories.

94 Gochenour, Penetration of Zaydì Islam; Smith, Early and Medieval History of Șana'a 'and Political History of the Islamic Yemen.

95 Smith, Political History of the Islamic Yemen, 129-139 and Medieval History of Sana'ä', 49-67; Serjeant, Modern History of Sana' ${ }^{\prime}$ ', 68-107.

96 Tuchscherer, Imams notables et bédouins; al-Marih, Najran. 
Only one group has not been included into the genealogy of Shākir. This group is locally referred to as manū' or qabä 'il al-wasat. The manū' live scattered among several segments of Dahm; their exact number is unclear. In Barat many suppose that manü 'until fairly recently made up a third of the Barat plateau's settled population. ${ }^{95}$ The $m a n \bar{u}$ ' are sedentary farmers and sharecroppers and subdivide into numerous groups which are loosely aligned with the tribal structures of the host group on whose territory they live. Unlike other low-status groups such as butchers or musicians, $\operatorname{manu}^{\prime}$ are reckoned tribesmen, yet not of full but rather subordinate tribal status. Dresch observed that manü' cannot make undertakings to escort or protect others in their own name. ${ }^{96}$ Local sources from the Barat region mentioned to me that the manū 'neither interfere in Dahm's meetings, nor do they play a role in Dahm's contracts or participate in Dahm's wars.

Although the manü 'are reckoned tribesmen and attach to the structure of Dahm they remain genealogically apart; locals speak of 'adam intisäbi-him ilā Dahm, i.e. their non-accession to the genealogy of Dahm. They remain apart from Dahm without having an independent genealogy of their own. Local tradition regards the manü' as the descendants of the indigenous sedentary population of al-Jawf, who had been settling in al-Jawf even before the installation of the Duhmah. The by-name (laqb) which refers to all of them is Banū Hilāl (i.e. not "noble« Arabs of Qaḥtānī stock). The word is that a large part of them left Yemen and took part in the Muslim Conquests of the early Islamic period. Dresch, in contrast, was told that the $m a n \bar{u}$ ' may have been left behind in Yemen at the great migration which followed the collapse of the Ma rib dam. ${ }^{97}$ Both versions make sense, because the penetration of external groups in al-Jawf would certainly not have had the same magnitude if the vast irrigated foothills bordering the desert areas did not decline: many people who inhabited these regions before the Common Era indeed formed a shield against them. ${ }^{98}$ Supporting evidence for the formation of the $m a n \bar{u}$ ' is thin; yet it appears as if the manū ' have their origin in the distant past of the ESA period, in which a tribe or a group did not need to know it's very origin and thus the extent of its "consanguinity" with other groups and tribes. With due caution, the $m a n \bar{u}^{\prime}$ can be regarded an anachronism, a vestige of the major change in social organization - the "culture shift", as Beeston (1972) called it - between the ESA period and that of al-Hamdāni, i.e. the shift from sha'b to qabilah, the shift from the idiom of territory to the idiom of shared descent.

Some of the $\operatorname{manu}^{\prime}$ 'are quite wealthy and in theory they could enter into marriage relations with Dahm, but in practice this hardly happens. Tribesmen of Dahm may marry women of the $m a n \bar{u}^{\prime}$ but they refuse to give their females to them. ${ }^{99}$ The non-exchange of women indicates

95 Dresch, Rules of Baraț, 37.

96 Dresch, Rules of Barat, 35.

97 Dresch, Rules of Barat, 37.

98 Robin, Pénétration des Arabes.

99 An interesting comparative case is the difference in status between the sādah (sing. sayyid) and the tribes. The sädah are an immigrant community living in tribally oriented areas, and genealogical rigidity seems to have been an appropriate strategy to enable the sädah to survive as a coherent group (Puin, Yemeni hijrah Concept of Tribal Protection, 484). But although the sādah sustain their exclusive status within these parts of Yemeni society through the principles of patrilineality and endogamy, endogamy is practiced much more stringently regarding the sharifahs (female descendants of the prophet); for sädah it is quite legitimate to marry tribal women, and their offspring will then be in turn of sayyid stock. For marriage patterns between tribes and sädah, see Serjeant, South Arabia, 227, 238-239; Gingrich and Heiss, Ethnographie der Provinz Sa'da, 19; Gingrich, How the Chiefs' Daughters Marry; Mundy, Domestic Government, 48, 173-175; vom Bruck, Islam, Memory, and Morality in Yemen, 131-162. 
the absence of equality between Dahm and the manü', i.e. the manū' are not reckoned fully haläl by Dahm. Heiss has elaborated in regard to groups without common genealogy among the historic Khawlān Quḍa ah based in the Șa 'dah area that the word halal (in addition to being known from the religious-legal sphere meaning "allowed«, e.g. the meat of ritually slaughtered animals) can also have the meaning of equivalence between people and tribal groups, an equivalence that manifests itself in the possibility of entering into mutual marital relationships, which are an important prerequisite for the fusion of genealogies. ${ }^{100}$ Dahm tribesmen justify the absence of mutual marital relationship with $m a n \bar{u}$ ' by saying that $\operatorname{man} \bar{u}$ ', albeit tribesmen, are "weak" (mustada'f) both in numerical terms and in terms of power, i.e. the manü cannot provide the same protection (of family members, in-laws, guests, protégés, etc.) like a full tribesman of Dahm.

The genealogical exclusion of the manü is remarkable because as a rule of thumb, we have seen, small and weak tribal groups were frequently accepted as allies by larger, presumably stronger ones. These groups were fully integrated in Dahm's nasab and society; in fact they disappeared into the host group (Dahm) and eventually came to be viewed as the host's agnates. Yet in the case of the man $\bar{u}$ ' their perceived weakness is often cited as a reason for the fact that the $m a n \bar{u}^{\prime}$ - in contrast to the lineage rumps of other tribal groups which were threatened with marginalization or even extinction - did not fuse with collateral lineages of Dahm and could not manage to adopt Dahm genealogy in order to become a coequal part of the dominant group's tribal law and status. In consequence the manū' retained their separate identities for centuries. Such cases of differentiation within the same tribal status group are rare, but they occur; cases are documented among the historic Khawlān Quḍāah in Yemen, Quraysh in Hijāz, and for Sulubbah in Northern Arabia. ${ }^{101}$ Among these groups the social class-system is so firmly rooted that it is not even possible for Islam to carry through its demands for its abolition..$^{102}$

In the eyes of Dahm, manü ' do not embody - whether rightly or wrongly is questionable - those qualities for which al-Hamdāni and the early Arab poets praise South Arabia's horsemen of Qahțānī origin. Manū ' do not belong to this class of heroes, who were accruing honour and glory as rider-warriors on horseback (also horses being an animal that appears and spreads rather late in Yemen ${ }^{103}$ ). As we have seen, a tribesman is expected to be sharif, qawì, māni', i.e. noble, strong, and able to protect the weak, and Duhma/Dahm perfectly encapsulate and exemplify these qualities. In fact up to our time these attributes are the blueprint for the tribal status and honour of the tribesmen of Dahm, who were still dreaded during the 1960s civil war in Yemen for being the "toughest fighting material in the Yemen [...], generally feared for their lawlessness and rapacity «. ${ }^{104}$ And Dahm are not just any host tribe, according to al-Hamdāni they belong to the most prestigious and strongest tribes of Qaḥ̣̂ān. Al-Hamdānī himself compared Duhmah with Quraysh in Mecca. Al-Hamdānī's language of honour and chivalry is therefore both inclusive and exclusive, it provides responses to the questions "Who we are? « as well as "Who is not like us? « and, relatedly, "Who does not belong to us?«

100 Heiss, Tribale Selbstorganisation und Konfliktregelung, 132.

101 Heiss, Tribale Selbstorganisation und Konfliktregelung, 92; Landau-Tasseron, Status of Allies; Dostal, Evolution of Bedouin Life, 14.

102 Dostal, Evolution of Bedouin Life, 14.

103 Robin, Pénétration des Arabes, 88.

104 Schofield, Boundary disputes, 707. 
It is, however, intriguing that a considerable part of Shākir - and of Dahm in particular - do not seem to be the original inhabitants of the country, of which heroes and heirs they are praised by al-Hamdāni. At the time of al-Hamdāni the Duhmah were already a product of massive immigrations of tribes from elsewhere, a constant flux of populations, which still continued far beyond the tenth century. Seen in this light, the Qahțān symbol of unity as well as the genealogies, panegyric poetries and semi-legendary traditions of al-Hamdānīs al-Iklìl served to evoke a vision of community and common identities among the heterogeneous societies of South Arabia and to legitimize them as heirs of a country and its splendid history, which in parts was not inherently their own.

\section{Acknowledgements}

My primary thanks are addressed to many families and genealogy experts from the areas of al-Jawf and eastern Șa'dah from whom I was allowed to learn about their genealogy and history, and whose exceptional friendship I appreciated. For this reason I owe special thanks to members of the families Abū Rās, al-'Ansī, al-'Awjarī, al-Ḍahyaānī, Dughsān, Ḥaydar, Ḥubaysh, Juzaylān and Shayhat, to name a few, for their generous and tireless support. Clearly, the responsibility for all insufficiencies and mistakes is completely mine. My sincerest thanks are also addressed to my colleagues at the Viennese Institute for Social Anthropology (ISA), Andre Gingrich, Johann Heiss, Daniel Mahoney and Eirik Hovden, as well as Matthew Steele (Harvard), for their helpful comments and critiques of the manuscript draft. This work was supported by the Austrian Science Fund (FWF) within the scope of the VISCOM project F42: Visions of Community). 


\section{References}

al-'Abbāsī al-'Alawī, 'Alī b. Muhạmmad b. 'Ubayd Allah, Sìrat al-Hādì ilā al-Haqq Yahyā b. al-Husayn b. al-Qäsim (Beirut, 1981).

al-Ansari, Abd al-Rahman, Qaryat al-Faw, in: Ali al-Ghabban, Béatrice André-Salvini and Françoise Demange (eds.), Routes d'Arabie: archéologie et histoire du royaume d'Arabie Saoudite (Paris, 2010) 310-363.

Arbach, Mounir, La situation politique du Jawf au Ier millénaire avant J.-C., Chroniques yéménites 11 (2003). Retrieved on 17 May 2016: http://cy.revues.org/146.

Arendonk, Cornelis van, De opkomst van het Zaidietische Imamaat in Yemen (Leiden, 1919).

Bamyeh, Mohammed, The Nomads of Pre-Islamic Arabia, in: Dawn Chatty (ed.), Nomadic Societies in the Middle East and North Africa: Entering the 21st Century (Leiden, 2006) 33-48.

Bédoucha, Géneviève, Une tribu sédentaire: La tribu des hautes plateaux yéménites, L'Homme 102/27 (1987) 139-150.

Bédoucha, Géneviève, Le cercle des proches: La consanguinité et ses détours (Tunisie, Yémen), in: Pierre Bonte (ed.), Épouser au plus proche: Inceste, prohibitions et stratégies matrimoniales autour de la Méditerranée (Paris, 1994) 189-219.

Beeston, Alfred F. L., Kingship in Ancient South Arabia, Journal of the Economic and Social History of the Orient 15/3 (1972) 256-268.

Beeston, Alfred F. L., Warfare in Ancient South Arabia (2nd-3rd centuries A.D.) (London, 1976).

Bonte, Paul. Egalité et hiérarchie dans une tribu maure: les Awlād Qaylān de l'Adrar mauritanien, in: Paul Bonte, Édouard Conte, Constant Hamès and Abdel Wedoud Ould Cheikh (eds.), Al-Ansāb: La quête des origines. Anthropologie historique de la société tribale arabe (Paris, 1991) 145-199.

Bonte, Paul and Conte, Édouard, La tribu arabe: Approches anthropologiques et orientalistes, in: Paul Bonte, Édouard Conte, Constant Hamès and Abdel Wedoud Ould Cheikh (eds.), Al-Ansāb: La quête des origines. Anthropologie historique de la société tribale arabe (Paris, 1991) 13-48.

Brandt, Marieke, Rückblick auf das Goldene Zeitalter des Jawf: Das Beduinenfestival Mahrajān Qarnāw als eine bemerkenswerte Friedensinitiative in einer krisengeschüttelten Provinz des Jemen, Jemen-Report 42/1 (2011) 34-39.

Brandt, Marieke, The Contemporary Structures and Historical Formation of the Khawlān and Jumāah Tribes in Șa'dah, Northwest Yemen, Anthropology of the Middle East 9/1 (2014) 59-82.

Brandt, Marieke, Inhabiting Tribal Structures: Leadership Hierarchies in Tribal Upper Yemen (Hamdān \& Khawlān b. 'Āmir), in: Andre Gingrich and Siegfried Haas (eds.), Southwest Arabia across History: Essays to the Memory of Walter Dostal (Vienna, 2015) 91-116.

Vom Bruck, Gabriele, Islam, Memory, and Morality in Yemen. Ruling Families in Transition (New York, 2005).

Caskel, Werner, Ğamharat an-nasab: Das genealogische Werk des Hišäm ibn Muhammad alKalbi, 2 vols. (Leiden, 1966).

Caton, Steven, Power, Persuasion, and Language: A Critique of the Segmentary Model in the Middle East, International Journal of Middle East Studies 19/1 (1987) 77-101.

Conte, Édouard, Entrer dans le sang: Perceptions arabes des origines, in Pierre Bonte, Édouard Conte, Constant Hamès and Abdel Wedoud Ould Cheikh (eds.), Al-Ansāb: La quête des origines. Anthropologie historique de la société tribale arabe (Paris, 1991) 55-100. 
Dostal, Walter W., The Evolution of Bedouin Life, in: Francesco Gabrieli (ed.), L'antica societa beduina (Rome, 1959) 11-33.

Dostal, Walter W., The Transition from Cognatic to Unilinear Descent Systems in South Arabia, in: Andre Gingrich, Silvia Haas, Siegfried Haas and Gerhard Paleczek (eds.), Kinship, Social Change, and Evolution: Proceedings of a Symposium held in Honour of Walter Dostal (Vienna, 1989) 47-62.

Dresch, Paul, The Position of Shaykhs Among the Northern Tribes of Yemen, Man 19/1 (1984) 31-49.

Dresch, Paul, The Significance of the Course Events Take in Segmentary Systems, American Ethnologist 13/2 (1986) 309-324.

Dresch, Paul, Tribes, Government, and History in Yemen (Oxford, 1989).

Dresch, Paul, The Tribes of Hāashid-wa-Bakil as Historical and Geographical Entities, in: Alan Jones (ed.), Arabicus Felix, Luminosus Britannicus: Essays in Honour of A. F. L. Beeston on his Eightieth Birthday (Reading, 1991) 8-24.

Dresch, Paul, The Rules of Barat: Tribal Documents from Yemen (Sana'a, 2006).

Duri, Abd al-Aziz, The Rise of Historical Writing among the Arabs (Princeton, 1983).

Dussaud, René, La pénétration des Arabes en Syrie avant l'Islam (Paris, 1955).

Evans-Pritchard, Evan, The Nuer: A Description of the Modes of Livelihood and Political Institutions of a Nilotic People (London, 1940).

Gellner, Ernest, Saints of the Atlas (London, 1969).

Ghanim, Muhammad Abduh, Yemeni Poetry from the Per-Islamic Age to the Beginning of the Modern Era, in: Werner Daum (ed.), Yemen: 300 Years of Art and Civilization in Arabia Felix (Innsbruck, 1987) 158-162.

Gingrich, Andre, Der Agrarkalender der Munebbih: Eine ethnologische Studie zu sozialem Kontext und regionalem Vergleich eines tribalen Sternenkalenders in Südwestarabien. Habilitation thesis (University of Vienna, 1989).

Gingrich, Andre, How the Chiefs' Daughters Marry: Tribes, Marriage Patterns and Hierarchies in Northwest-Yemen, in: Andre Gingrich, Silvia Haas, Siegfried Haas and Gerhard Paleczek (eds.), Kinship, Social Change, and Evolution: Proceedings of a Symposium held in Honour of Walter Dostal (Vienna, 1989) 75-85.

Gingrich, Andre, Südwestarabische Sternenkalender: Eine ethnologische Studie zu Struktur, Kontext und regionalem Vergleich des tribalen Agrarkalenders der Munebbih im Jemen, Wiener Beiträge zur Ethnologie und Anthropologie 7 (Wien, 1994).

Gingrich, Andre, The Prophet's Smile and Other Puzzles: Studying Arab Tribes and Comparing Close Marriages, Social Anthropology 3/2 (1995) 147-170.

Gingrich, Andre, Konzepte und Perspektiven sozial- und kulturanthropologischer Forschung im Vorderen Orient, Mitteilungen der Anthropologischen Gesellschaft in Wien 127 (1997) 5967.

Gingrich, Andre, Multiple Histories: Three Journeys through Academic Records, Medieval Yemen, and Current Anthropology's Encounters with the Past, History and Anthropology 26/1 (2015) 110-128.

Gingrich, Andre, Galactic Polities: Anthropological Insights for Understanding States in Yemen's Pre-Ottoman Past, in: Andre Gingrich and Siegfried Haas (eds.), Southwest Arabia across History: Essays to the Memory of Walter Dostal (Vienna, 2015).

Gingrich, Andre and Heiss, Johann, Beiträge zur Ethnographie der Provinz Sa'da, Nordjemen (Vienna, 1986). 
Gochenour, David Thomas, The Penetration of Zaydī Islam into Early Medieval Yemen, Ph. D. thesis (Harvard University, 1984).

al-Ḥajrī, M. A., Majmu' buldān al-yaman wa qabā'il-hā, ed. Ismāîl b. 'Alī al-Akwa', 2 vols. (Șan'ä', 1996).

al-Hamdānī, Abū Muhammad al-Ḥasan b. Aḥmad b. Ya qūb, Kitāb al-iklìl min akhbār al-Yaman wa ansāb Himyar, ed. Muhibb al-Dīn al-Khațīb (Cairo, 1948).

al-Hamdānī, Abū Muhammad al-Hasan b. Aḥmad b. Ya 'qūb, Kitäb al-iklìl al-juz'al-thāmin, ed. Nabih Amin Faris (London, 1940).

al-Hamdānī, Abū Muḥammad al-Ḥasan b. Aḥmad b. Ya'qūb, Șifat jazìrat al-'arab. Al-Hamdani's Geographie der Arabischen Halbinsel, ed. David H. Müller (Leiden, 1968).

Hamès, Constant, La filiation généalogique (nasab) dans la société d'Ibn Khaldun, L’Homme 102/27 (1987) 99-118.

Hamès, Constant, De la chefferie tribale à la dynastie étatique: Généalogie et pouvoir à l'époque almohado-hafside (XIIe-XIVe siècles), in: Pierre Bonte, Édouard Conte, Constant Hamès and Abdel Wedoud Ould Cheikh (eds.), Al-Ansāb: La quête des origines. Anthropologie historique de la société tribale arabe (Paris: 1991) 101-137.

Heiss, Johann, Die Landnahme der Hawlān nach Al-Hamdānī, in: Roswitha Stiegner (ed.), Aktualisierte Beiträge zum 1. Internationalen Symposium `Südarabien interdisziplinär an der Universität Graz mit kurzen Einführungen zu Sprach- und Kulturgeschichte. In Memoriam Maria Höfner (Graz, 1997) 53-68.

Heiss, Johann, Tribale Selbstorganisation und Konfliktregelung: Der Norden des Jemen zur Zeit des ersten Imams (10. Jahrhundert). Unpublished Ph. D. thesis (University of Vienna, 1998).

Höfner, Maria, Die Beduinen in den vorislamischen arabischen Inschriften, in: Francesco Gabrieli (ed.), L'antica societa beduina (Rome, 1959) 53-68.

Jāzim, Muhammad 'Abd al-Raḥim and Arbach, Mounir (eds.), Les Mérites véritables de Qahțān et du Yémen (Auteur anonyme) (Sana'a, 2009).

Kennedy, Hugh, From Oral Tradition to Written Record in Arabic Genealogy, Arabica 44 (1997) 531-544.

Landau-Tasseron, Ella, Adoption, Acknowledgement of Paternity and False Genealogical Claims in Arabian and Islamic Societies, Bulletin of the School of Oriental and African Studies 66/2 (2003) 169-192.

Landau-Tasseron, Ella, Alliances among the Arabs, al-Qantara 26/1 (2005) 141-173.

Landau-Tasseron, Ella, The Status of Allies in Pre-Islamic and Early Islamic Arabian Society, Islamic Law and Society 13/1 (2006) 7-32.

Lecker, Michael, Tribes in Pre- and Early Islamic Arabia, in: Michael Lecker (ed.), People, Tribes and Society in Arabia around the Time of Muhammad (Aldershot, 2005).

Mahoney, Daniel, Cultural Heritage and Identity Politics in Early Medieval South Arabia, in: Andre Gingrich and Siegfried Haas (eds.), Southwest Arabia across History: Essays to the Memory of Walter Dostal (Vienna, 2015) 67-78.

Mahoney, Daniel, The Political Construction of a Tribal Genealogy from Early Medieval South Arabia, in: Walter Pohl, Christina Lutter and Eirik Hovden (eds.), Meanings of Community across Eurasia (Leiden) forthcoming.

al-Maqḥafì, Ibrāhīm, Mu jam al-buldān wa al-qabā il al-yamaniyyah (Șan 'à', 2002).

al-Maqhafī, Ibrāhīm, Mausūat al- 'alqāb al-yamaniyyah (Beirut, 2010).

Mundy, Martha, Domestic Government: Kinship, Community and Polity in North Yemen (London, 1995). 
Al-Marih, Saleh, Najran, in: Ali al-Ghabban, Béatrice André-Salvini, Françoise Demange (eds.), Routes d'Arabie: Archéologie et histoire du royaume d'Arabie Saoudite (Paris, 2010) 356-371.

Olinder, Gunnar, The Kings of Kinda of the Family of Ākil al-Murār (Lund, 1927).

Ould Cheikh, Abdel Wedoud, La tribu comme volonté et comme représentation: Le facteur religieux dans l'organisation d'une tribu maure: Les Awlād Abyayrī, in: Pierre Bonte, Édouard Conte, Constant Hamès and Abdel Wedoud Ould Cheikh (eds.), Al-Ansāb: La quête des origines, Anthropologie historique de la société tribale arabe (Paris, 1991) 201-238.

Peters, Emrys, The Proliferation of Segments in the Lineage of the Bedouin of Cyrenaica, Journal of the Anthropological Institute of Great Britain and Ireland 90/1 (1960) 29-53.

Philby, Harry, Arabian Highlands (Ithaca, 1952).

Piotrovsky, Mikhail Borisovich, Al-Hamdani and the Qahtanide Epos, in: Yusuf Abdullah (ed.), Al-Hamdani, a great Yemen scholar (San'à', 1986) 17-25.

Puin, Gerd-Rüdiger, The Yemeni hijrah Concept of Tribal Protection, in: Tarif Khalidi (ed.), Land Tenure and Social Transformation in the Middle East (Beirut, 1984) 483-494.

Robin, Christian, Les hautes-terres du nord-Yémen avant l'Islam: Recherches sur la géographie tribale et religieuse du Hawlān Qudāà et du pays de Hamdān (Istanbul, 1982).

Robin, Christian, La pénétration des Arabes nomades au Yémen, Revue du monde musulman et de la Méditerranée 61 (1991) 71-88.

Schofield, Richard, Arabian Boundary Disputes, vol. 20: Saudi Arabia - Yemen: 1913-1992 (Slough, 1992).

Serjeant, Robert B., South Arabia, in: Christoffel A. O. van Nieuwenhuijze (ed.), Commoners, Climbers and Notables (Leiden, 1977) 226-247.

Serjeant, Robert B., The Post-Medieval and Modern History of Șana 'à', in: Robert B. Serjeant and Ronald Lewcock (eds.), Șana 'ä', an Arabian Islamic City (London, 1983) 68-107.

Smith, G. Rex., The Early and Medieval History of Șana'a' in in Robert B. Serjeant and Ronald Lewcock (eds.), Sana 'ä', an Arabian Islamic City (London, 1983) 49-67.

Smith, G. Rex, The Political History of the Islamic Yemen down to the First Turkish Invasion (1-945/622-1538), in: Werner Daum (ed.), Yemen: 300 Years of Art and Civilization in Arabia Felix (Innsbruck, 1987) 129-139.

Smith, G. Rex., Madhhhid], in: Peri Bearman, Thierry Bianquis, Clifford E. Bosworth, Emeri J. van Donzel and Wolfhart P. Heinrichs, Encyclopaedia of Islam (2nd edition) (Leiden, 2013).

Steffen, Hans, Yemen Arab Republic: Final Report on the Airphoto Interpretation Project of the Swiss Technical Co-Operation Service, Berne (Zurich, 1978).

Szombathy, Zoltan, Genealogy in Medieval Muslim Societies, Studia Islamica 95 (2002) 5-35.

Szombathy, Zoltan, The Roots of Arabic Genealogy: A Study in Historical Anthropology (Piliscsaba, 2003).

Tuchscherer, Michel, Imams, Notables et Bédouins du Yémen au XVIIIe siècle (Cairo, 1992).

Varisco, Daniel Martin, Metaphors and Sacred History: The Genealogy of Muhammad and the Arab >Tribe‘, Anthropological Quarterly 68/3 (1995) 139-156.

Weir, Shelagh, A Tribal Order: Politics and Law in the Mountains of Yemen (Austin, 2007).

Wilson, Robert, Al-Hamdānī's Description of Hāshid and Bakīl, Proceedings of the Seminar for Arabian Studies 11 (1981) 95-104.

Wilson, Robert, Gazetteer of Historical North-West Yemen (Hildesheim, 1989).

Wissmann, Herrmann von, Zur Geschichte und Landeskunde von Alt-Südarabien (Vienna, 1964). 